Article

\title{
Integrated Water Management at the Peri-Urban Interface: A Case Study of Monterey, California
}

\author{
Bridget C. Gile ${ }^{1,2} \mathbb{D}$, Paul A. Sciuto ${ }^{3}$, Negin Ashoori ${ }^{1,2}$ and Richard G. Luthy ${ }^{1,2, * \mathbb{C}}$ \\ 1 Re-Inventing the Nation's Urban Water Infrastructure (ReNUWIt), National Science Foundation Engineering \\ Research Center, Stanford, CA 94305, USA; bgile@stanford.edu (B.C.G.); neashoori@gmail.com (N.A.) \\ 2 Department of Civil \& Environmental Engineering, Stanford University, Stanford, CA 94305, USA \\ 3 Monterey One Water, Monterey, CA 93940, USA; paul@my1water.org \\ * Correspondence: luthy@stanford.edu; Tel.: +1-650-721-2615
}

Received: 18 November 2020; Accepted: 17 December 2020; Published: 21 December 2020

\begin{abstract}
Climate change, drought, and chronic overdraft represent growing threats to the sustainability of water supplies in dry environments. The Monterey/Salinas region in California exemplifies a new era of integrated or "one water" management that is using all of the water it can get to achieve more sustainable supplies to benefit cities, agriculture, and the environment. This program is the first of its kind to reuse a variety of waters including wastewater, stormwater, food industry processing water, and agricultural drainage water. This study investigates the partnerships, projects, and innovations that shape Monterey's integrated water network in order to better understand the challenges and opportunities facing California communities as they seek to sustainably manage peri-urban water supplies. Water reuse in the Monterey region produces substantial economic and environmental benefits, from tourism and irrigation of high-value crops to protection of groundwater and increases in environmental flows and water quality. Water resource managers in other communities can learn from Monterey's success leveraging local needs and regional partnerships to develop effective integrated water solutions. However, key challenges remain in resolving mismatched timing between water availability and demand, funding alternative water supplies, and planning effectively under uncertainty. Opportunities exist to increase Monterey's recycled water supply by up to $50 \%$, but this requires investment in seasonal storage and depends on whether desalination or additional recycling forms the next chapter in the region's water supply story. Regulatory guidance is needed on seasonal subsurface storage of tertiary-treated recycled water as distinct from potable recharge. By increasing the supply of recycled water to Monterey's indirect potable use system, the region's potential need for seawater desalination may be delayed as much as 30 years, resulting in cost and energy savings, and giving the opportunity to resolve present planning concerns.
\end{abstract}

Keywords: one water management; recycled water; groundwater replenishment; desalination; Monterey; Salinas; California

\section{Introduction}

Water supply reliability in California faces increased stress due to climate change and more severe droughts, along with competing demands between cities and agriculture while sustaining environmental flows [1]. This situation is exemplified by the Monterey/Salinas region, which is a microcosm of the state itself. For this region, climate change is expected to result in worsening droughts, accelerated seawater intrusion, and increased water demand [2,3]. The County of Monterey has a long history of being an economic hub for the central coast of California with adjacent tourism and agricultural industries, which are dependent on a reliable water supply. The county attracts 4.6 million overnight visitors annually, who generate $\$ 2.8$ billion to the region each year [4]. The county also 
boasts $\$ 4.4$ billion in annual crop production [5], ranking the fourth highest among California counties in 2019 [6].

Sustainable water resource management is especially critical for Monterey County because the region is independent of any state or federal water supply projects and because of past heavy reliance on local surface and groundwater supplies $[2,7,8]$. Although conservation and efficiency measures can extend the sufficiency of existing supplies [9], Monterey Peninsula residents have already achieved high conservation levels of 58 gallons per person per day [10], and they pay among the highest water rates in the nation [11]. The recent drought in the state, from 2012 to 2016, placed additional constraints on the local water supply and created heightened public awareness of the finite resource [12]. Resource management organizations across the county have since implemented a variety of projects and plans to address the vulnerability of their water, both in volume and in quality, especially for environmental concerns. A map of the cities and principal water management features is shown in Figure 1.

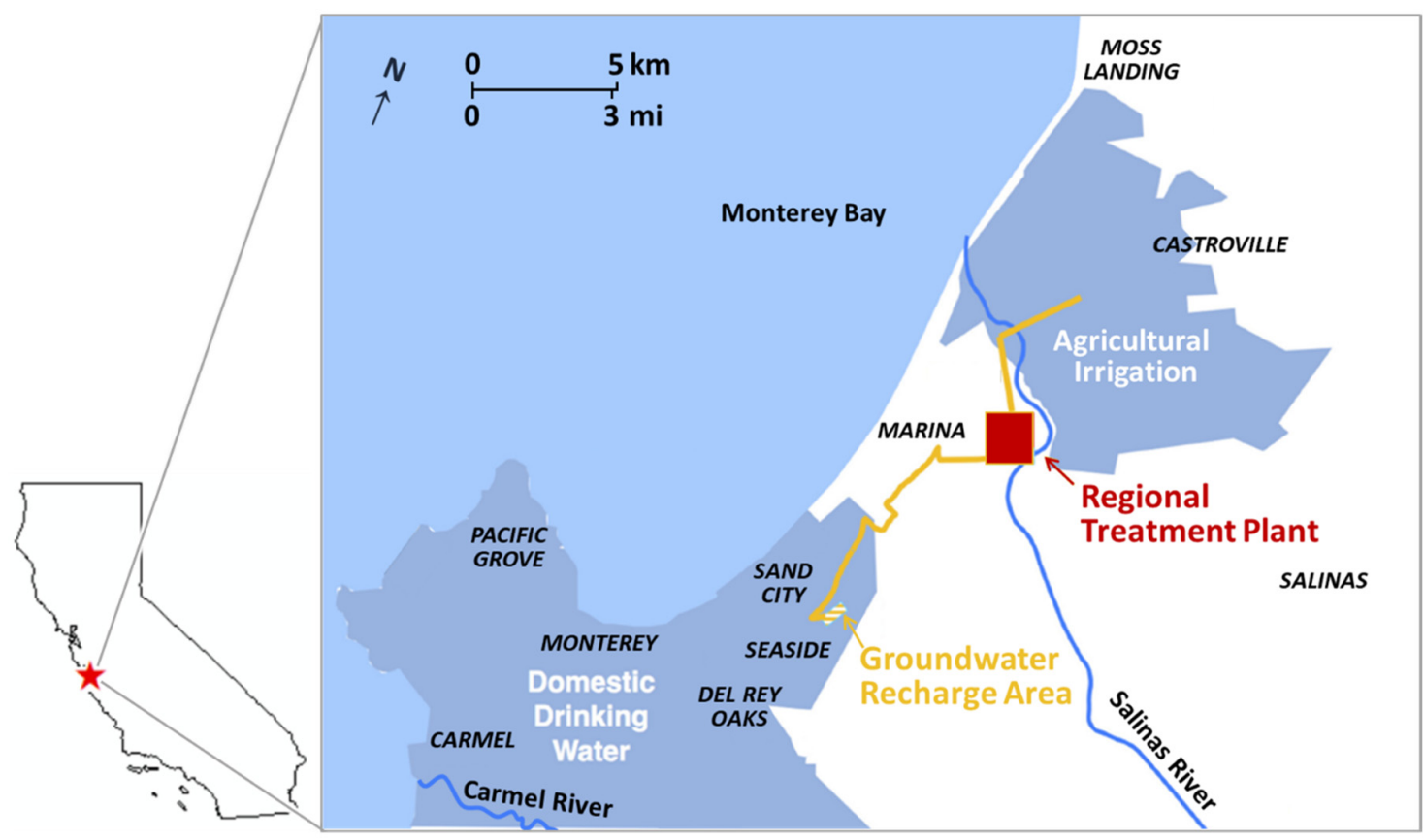

Figure 1. Map of Monterey area rivers, communities, and regional treatment center. Customer areas receiving recycled water are shaded in blue (adapted from [13]).

This paper investigates the development of Monterey's integrated water management network and highlights key innovations that allow this network to more effectively serve the area's agricultural and residential communities. These findings support a discussion of current and future issues facing water sustainability in the Monterey/Salinas region, which serves as a case study for water-stressed communities seeking sustainable water supply solutions. This paper identifies strategies to enhance one water management both in the study region and in other peri-urban communities that can benefit from Monterey's story in light of what has worked and lessons for regional approaches.

\section{Methods}

This article analyzes the Monterey/Salinas region as a case study for communities in water-stressed environments striving to responsibly meet diverse water needs. This work aims to understand the planning and decision processes leading to Monterey's present water management programs and to identify challenges and opportunities for sustainable management into the future. To support these research goals, this study relied on agency reports, design documents, and regulatory decisions to obtain data about the history, agreements, design, and performance of Monterey's one water programs. The authors build on these findings with discussions of storage, funding, demand, and uncertainty 
and present conclusions about key drivers and lessons that will shape the water supply future of Monterey and other peri-urban communities. Inclusion of varied source materials facilitates access to perspectives from diverse stakeholders, including Monterey area growers and residents, civic action groups, and corporate and agency leadership. This scope allows the work to address complex topics of water scarcity, management, and governance with data and perspectives beyond what is represented in the existing scientific literature.

\section{Results and Discussion}

\subsection{Developing an Integrated Water Network}

\subsubsection{Restrictions on Conventional Water Supplies}

The major domestic water supplier on the Monterey Peninsula, the private utility company California American Water (CalAm), has been mandated to reduce reliance on unsustainable water sources. In 1995 it was notified of its over-drafting from the Carmel River by over 12 million m³ (10,000 acre-feet/year; AFY) beyond its legal withdrawals of 4.2 million $\mathrm{m}^{3} / \mathrm{y}(3376 \mathrm{AFY})$, as detailed in State Order 95-10 [14]. In 2009, the State Water Resources Control Board issued a cease and desist order (WR 2009-0060) for excessive pumping of the Carmel River, which continued at 9 million $\mathrm{m}^{3} / \mathrm{y}$ (7000 AFY) beyond legal amounts [15]. The order required CalAm to stop its unlawful diversions from the Carmel River before a now-extended deadline of December 2021 [16].

The Monterey region also faces restrictions on groundwater use to attain sustainable groundwater management. The Seaside Groundwater Basin is managed under state adjudication since 2006 after measured water levels fell $6 \mathrm{~m}$ (20 ft) in 10 years [17-19]. The Salinas Valley Groundwater Basin has also experienced diminished storage and seawater intrusion from historic groundwater over-pumping [20]. The Groundwater Sustainability Plan for its high-priority 180/400-Foot Aquifer Subbasin outlines goals of increasing groundwater storage, halting seawater intrusion, improving groundwater quality, and reducing surface water depletion [21].

Local and state recognition of the need for more sustainable water management has led to restrictions on the Monterey region's conventional use of surface and groundwater resources. This changing perspective supports the goals of stabilizing groundwater levels, halting seawater intrusion, and preserving ecological flows, but it also curtails the water supply available to the region. To make up the difference, Monterey has turned to "one water" management to find new water sources within its own region.

\subsubsection{Castroville Seawater Intrusion Project}

In the early 1970s seawater intrusion was recognized as a growing threat to local groundwater supplies. At the same time, the federal Clean Water Act raised effluent discharge standards for municipal wastewater treatment plants, including those serving communities in the Monterey region [22]. To better address these waste management and water supply challenges, the Sanitation Districts of Monterey, Pacific Grove, and Seaside formed the regional agency Monterey One Water (M1W), formerly Monterey Regional Water Pollution Control Agency [22]. By 1989, the M1W joint power agreement included eleven members and one ex-officio member [23]. Present-day members are shown in Figure 2. 


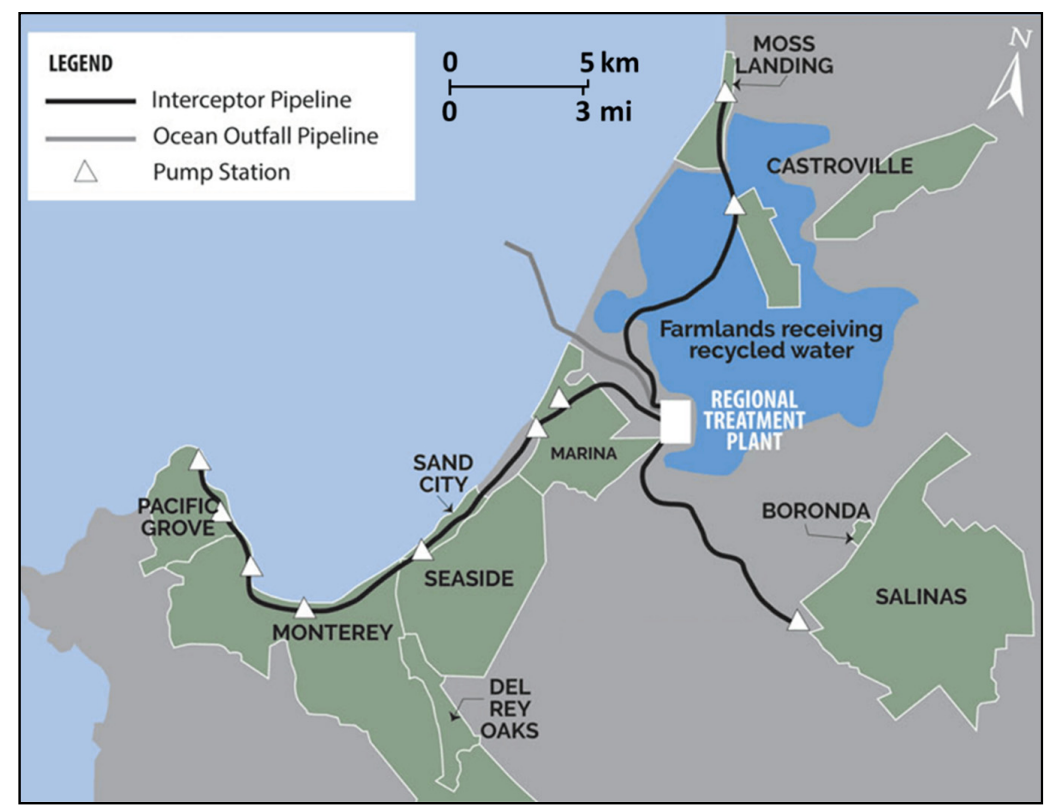

Figure 2. Monterey One Water member entities include Boronda County Sanitation District, Castroville Community Services District (including Moss Landing), Del Rey Oaks, Marina Coast Water District, Monterey, Pacific Grove, Salinas, Sand City, Seaside, and Monterey County (adapted from [24]).

After M1W was established in 1972, discussions with community leaders shaped the idea of developing an innovative water recycling program that could lessen the agricultural dependency on groundwater from the Salinas Valley Groundwater Basin [25]. The Central Coast Regional Water Quality Control Board affirmed this vision by recommending in its 1975 Basin Plan that municipal wastewater flows be redirected to a single regional plant for reuse opportunities including crop irrigation and Salinas River augmentation [26]. This goal prompted an eleven-year, foundational study titled Monterey Wastewater Reclamation Study for Agriculture, which showed for the first time that tertiary treated municipal wastewater could safely irrigate freshly edible crops, such as salad greens and berries [27]. The study evaluated sprinkler and furrow irrigation of raw vegetable crops and found that irrigation with tertiary treated wastewater did not result in elevated levels of pathogens or metals in the crops or soil.

Following the reuse study in 1990, M1W completed construction of a Regional Treatment Plant (RTP) [28] and partnered with the Monterey County Water Resources Agency (MCWRA) on a pair of projects that together would produce and distribute recycled water to Salinas Valley growers. The Salinas Valley Reclamation Project (SVRP) added tertiary treatment facilities to the newly constructed RTP, and the Castroville Seawater Intrusion Project (CSIP) installed a distribution system for the recycled water [29]. By 1998, CSIP began using the recycled water to irrigate approximately $49 \mathrm{~km}^{2}$ (12,000 acres) of cropland near the coastal town of Castroville through a "purple pipe" system [30]. The distinctive purple pipes indicate non-potable recycled water, an international color designation that was first used by the Irvine Ranch Water District in southern California [31]. Since its inception, CSIP has delivered an average of 24.1 million $\mathrm{m}^{3} / \mathrm{y}(19,500 \mathrm{AFY})$ annually, of which over $60 \%$ has been recycled water [30], and grower acceptance remains high [32]. In recent years, supplemental groundwater contributes approximately 6.8 million $\mathrm{m}^{3} / \mathrm{y}$ (5500 AFY) to this total annual supply, and Salinas River contributions average 4.2 million $\mathrm{m}^{3} / \mathrm{y}$ (3400 AFY) [21]. The reclamation projects have successfully slowed, but not halted the rate of inland seawater intrusion [30].

\subsubsection{Pure Water Monterey}

With groundwater supplies threatened by increasing salinity and Carmel River diversions curtailed by the state's cease and desist order, the peninsula's private water supplier, CalAm, supported a 
three-pronged regional solution to add desalination, aquifer storage and recovery, and potable reuse as new sources [33]. The desalination effort encountered numerous delays, so a potable reuse project was pursued independently by local water agencies with support from county and local leaders to demonstrate progress towards reducing unlawful Carmel River diversions [15,33]. This potable reuse project completed in 2020 was Pure Water Monterey (PWM), developed collaboratively by M1W and the Monterey Peninsula Water Management District (MPWMD) [34,35]. PWM produces 4.3 million $\mathrm{m}^{3} / \mathrm{y}$ (3500 AFY) of recycled water through full advanced treatment for injection into the Seaside Groundwater Basin [13], allowing a corresponding reduction in Carmel River diversions [36] and a similar reduction of secondary effluent to the Monterey Bay.

To ensure adequate source water for both CSIP and PWM recycled water efforts, the PWM project built infrastructure to supplement existing wastewater flows with four new sources of water: food processing/packaging flows referred to as "ag wash" (Figure 3), irrigation return flows from the Blanco Drain, surface runoff and irrigation return flows from the Reclamation Ditch, and urban stormwater runoff from the city of Salinas. The PWM project is the first of its kind to recycle water from such sources as runoff and food processing water in addition to municipal wastewater [37]. This novel approach furnishes additional water supply and reduces contaminant loading to Salinas River and Monterey Bay ecosystems [38]. The PWM project can divert more water from these new sources than the amount required for groundwater replenishment, resulting in additional supply available for tertiary treatment through CSIP. In future years, the new sources may be able to provide an extra 5.6 million $\mathrm{m}^{3} / \mathrm{y}$ (4500 AFY) of recycled water for agricultural irrigation [13].

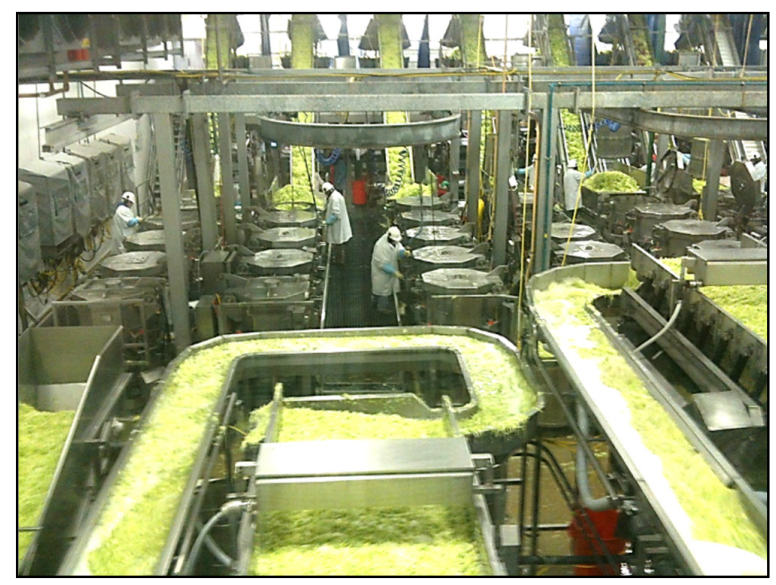

Figure 3. Salinas lettuce cutting and rinse operations contribute to "ag wash water", one of four new water sources collected for the Pure Water Monterey project (photo by R.G.L).

Advanced treatment that includes ozone, membrane filtration (MF), reverse osmosis (RO), and $\mathrm{UV} / \mathrm{H}_{2} \mathrm{O}_{2}$ advanced oxidation is used to produce potable recycled water for groundwater replenishment [39] (Appendix A). The PWM pilot study revealed that ozone pretreatment reduced fouling of the MF membranes, extending MF run times by a factor of four and supporting higher MF fluxes, which translated to cost and space savings at full scale [40]. In addition to improving MF performance, the ozone pretreatment provides added disinfection and destruction of many contaminants of possible concern from the varied water sources [13], and subsequent treatment steps guard against byproducts that may form during ozonation [41].

\subsubsection{Regional Urban Water Augmentation Project}

Alone among M1W members, the Marina Coast Water District (MCWD) retains the right to purchase recycled water from M1W, up to the amount of MCWD's wastewater contribution to the Regional Treatment Plant [29]. To utilize this available amount, MCWD developed the Regional Urban Water Augmentation Project (RUWAP) to supply its customers with 0.7 million m³/y (600 AFY) of 
recycled water for urban landscape irrigation [42]. The RUWAP shares a single recycled water pipeline with PWM, so its source water and treatment are identical to that of PWM. Since recycled water leaving the Advanced Water Purification Facility (AWPF) meets California Title 22 water quality standards for indirect potable reuse, the portion diverted for RUWAP exceeds the less stringent Title 22 standards applicable to nonpotable landscape irrigation use [42]. Despite the higher production costs of advanced treatment compared to tertiary treatment, cost savings from the shared conveyance infrastructure provide economical irrigation water for RUWAP customers.

\subsubsection{One Water}

The Regional Treatment Plant operated by M1W receives influent from communities throughout the Monterey Peninsula and northern Monterey County and delivers secondary treated water to the CSIP, PWM, and RUWAP projects. Ag wash, Blanco Drain, Reclamation Ditch, and Salinas stormwater flows are blended with raw municipal wastewater prior to entering the RTP, as shown in Figure 4. A portion of the secondary effluent continues to tertiary treatment at the adjacent SVRP facility, where it undergoes flocculation, multimedia filtration, and chlorine disinfection in compliance with state standards for unrestricted nonpotable reuse, prior to distribution for agricultural irrigation [43]. The remainder of the secondary effluent is diverted to the AWPF for treatment consisting of ozonation, membrane filtration, reverse osmosis, and UV disinfection with $\mathrm{H}_{2} \mathrm{O}_{2}$ [39]. This advanced treated water is destined for indirect potable reuse through PWM and for urban irrigation through RUWAP. Finally, excess secondary effluent not directed to tertiary or advanced treatment trains is blended with membrane concentrate and discharged to Monterey Bay [13].

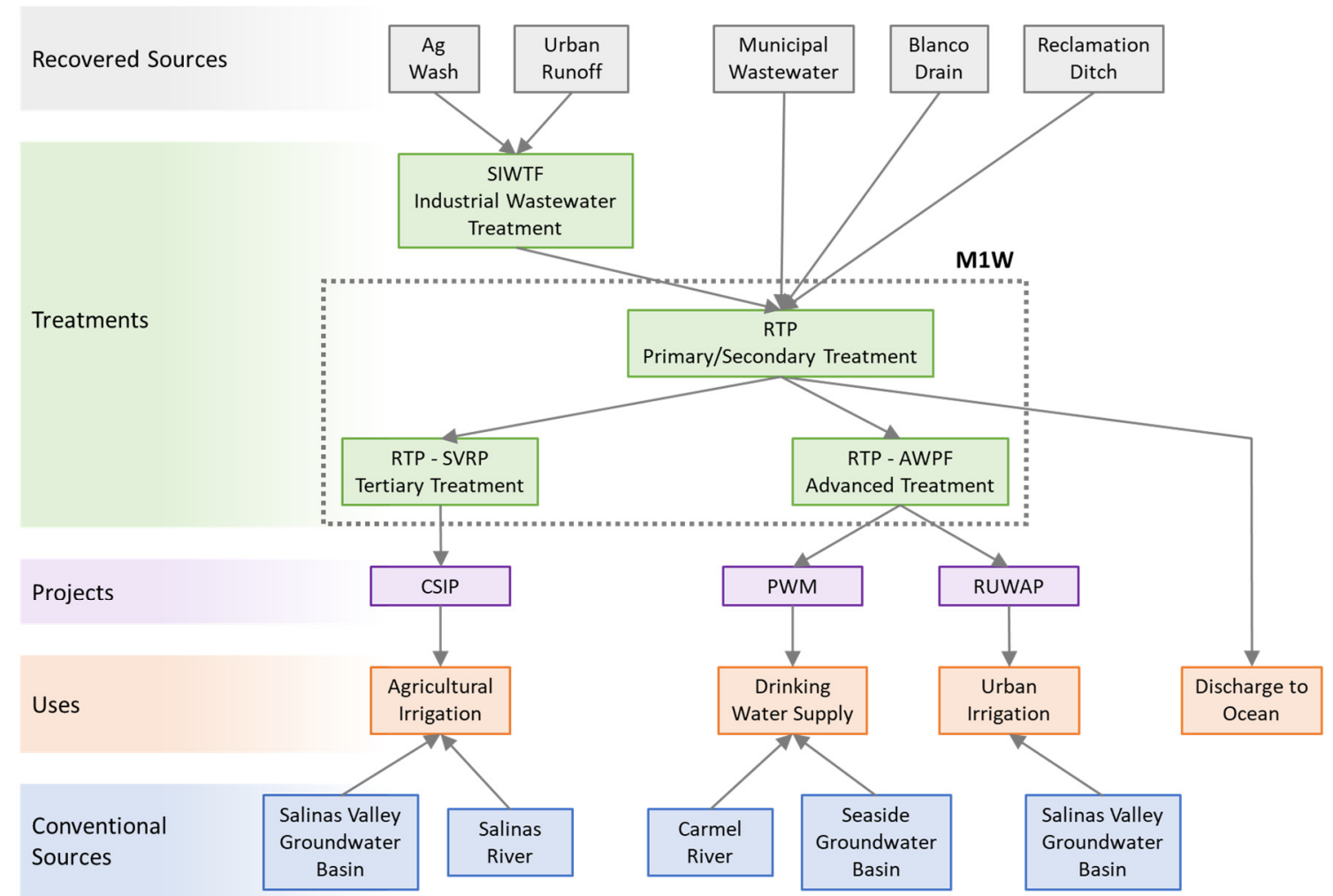

Figure 4. Conceptual diagram of Monterey's regional recycled water network, including water sourcing, treatment, and use. (Legend: SIWTF = Salinas Industrial Wastewater Treatment Facility, RTP $=$ Regional Treatment Plant, SVRP = Salinas Valley Reclamation Project, AWPF $=$ Advanced Water Purification Facility, CSIP = Castroville Seawater Intrusion Project, PWM = Pure Water Monterey, RUWAP $=$ Regional Urban Water Augmentation Project). 


\subsection{Novel Water Sourcing}

The novel water sources introduced by the PWM project represent a major innovation in water reuse. Together, the new sources from ag wash, Blanco Drain, Reclamation Ditch, and Salinas stormwater offer not only additional volume for reuse, but also a more diverse water supply portfolio. Figure 5 shows the location of the new sources within Monterey's recycled water network and highlights the regional scope of both contributions and benefits. Throughout the year, these new sources contribute between $0 \%$ and $36 \%$ of the total influent flow to the RTP, with municipal wastewater comprising the remaining $64-100 \%$ [13]. A description of the individual water sources, tertiary treatment for irrigation, and treatment concerns with new source waters is provided in Appendix A.

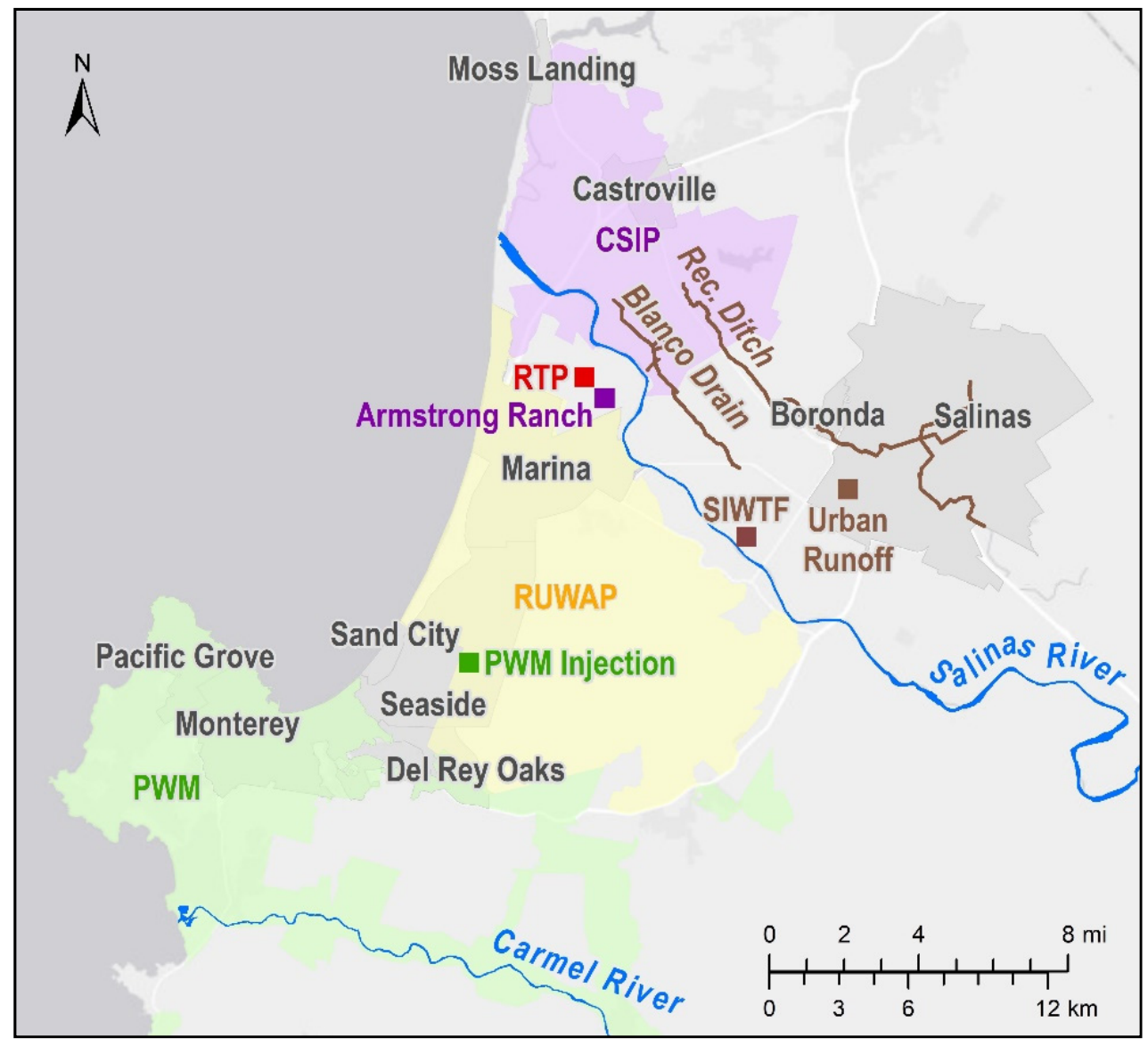

Figure 5. Map of Monterey's regional recycled water network, including wastewater contributors, new sources, treatment center, and project service areas.

The total monthly availabilities of each of the major source waters are displayed in Figure 6. During a typical year, new source waters are incorporated only during the summer months when additional flow is required to meet recycled water demand. The monthly flow allocated to each recycled water project is displayed in Figure 7. 
Municipal WW $n$ Ag Wash $\square$ Salinas Urban Runoff $\square$ Reclamation Ditch $\square$ Blanco Drain

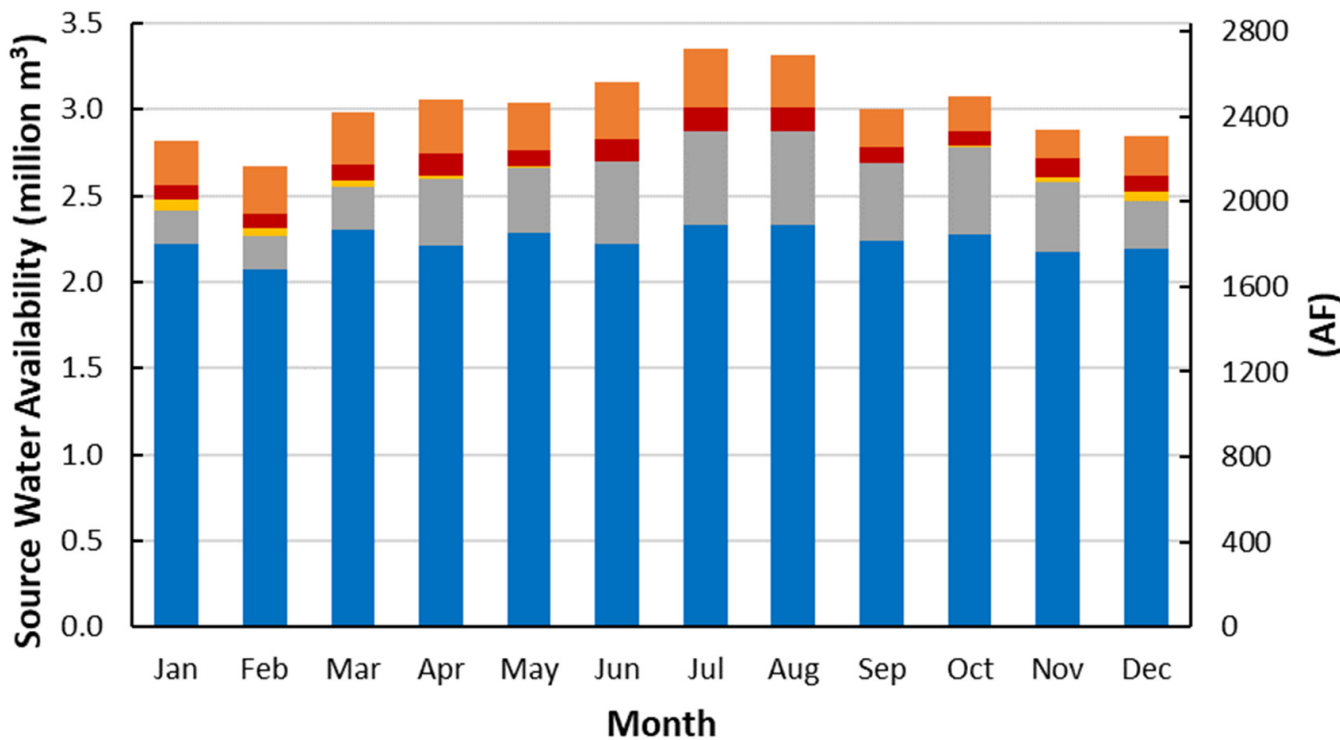

Figure 6. Source water availabilities during a normal/wet year (data from [44]).

$\square$ CSIP $\square$ PWM $\square$ RUWAP $\square$ Available

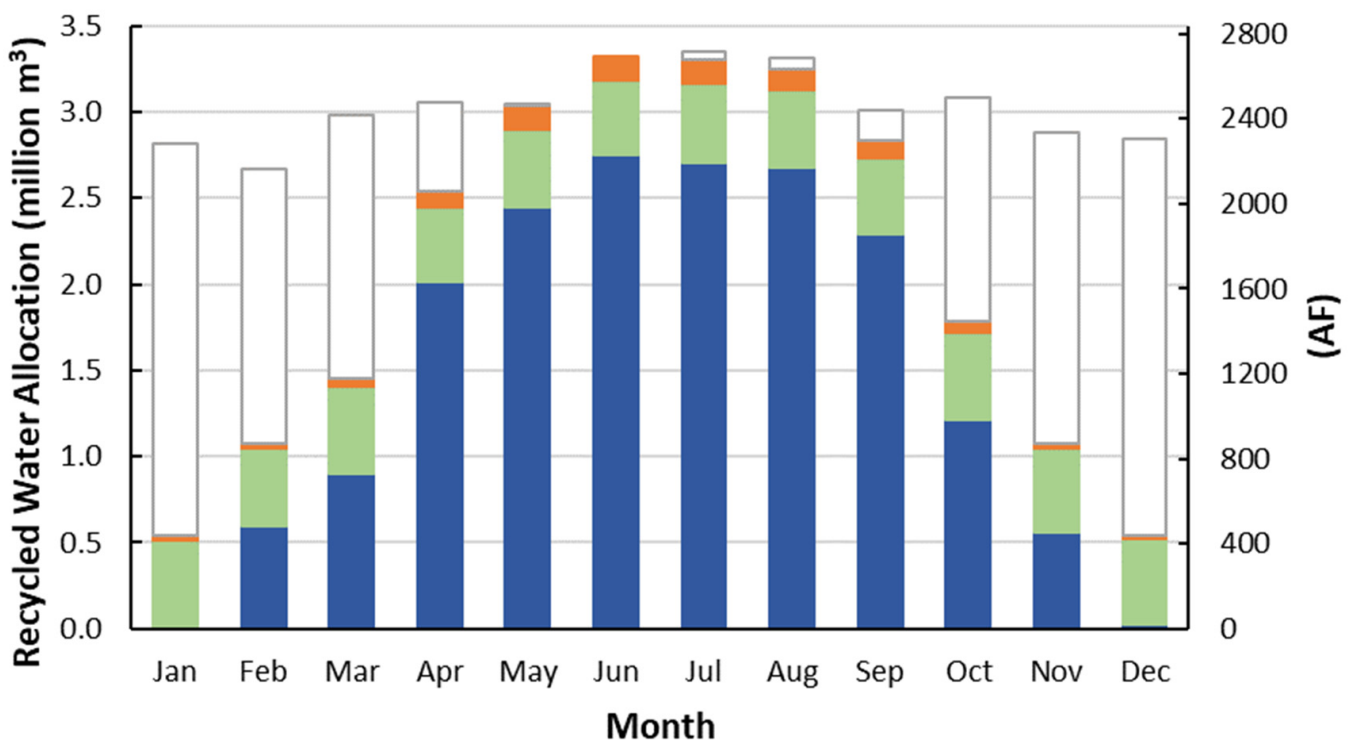

Figure 7. Recycled water distribution by project during a normal/wet year, showing irrigated agriculture (CSIP), potable water recharge (PWM), and urban irrigation (RUWAP). A substantial amount of water is available during the off-peak growing season (data from [44]).

The allocation of secondary effluent among CSIP, PWM, RUWAP, and the outfall varies substantially by season, according to the balance of water availability and respective demands. CSIP generally has the principle right to all wastewater flows entering the RTP, except for a 0.8 million $\mathrm{m}^{3}$ (650 acre-feet; AF) summer allocation to M1W, as well as any claim by the MCWD for amounts up to its own wastewater contribution, which includes a 0.4 million $\mathrm{m}^{3}$ (300 AF) summer allocation [29,45,46]. Rights to PWM's new water sources are split approximately equally between the CSIP and PWM projects [45]. During the summer growing season when irrigation demand is greatest, CSIP utilizes all of the secondary effluent available to it [44], as well as approximately 11 million $\mathrm{m}^{3} / \mathrm{y}$ (8900 AFY) of supplemental flows from groundwater wells and the Salinas River [21]. By contrast, during the winter when irrigation demand is low, 7-10 million $\mathrm{m}^{3}$ (6000-8000 AF) of secondary wastewater effluent is 
discharged through the ocean outfall [47], and available flows from other sources are not diverted for treatment. These excess winter flows represent a large potential source of recycled water supply.

While excess water is available for recycling each year, utilization of this water is limited by mismatched seasonal patterns of availability, demand, and treatment capacity. To mitigate some of this temporal challenge, the Monterey Peninsula leverages innovative collaborations between agricultural and urban reuse efforts. The PWM project, for instance, includes a banking protocol to store up to 1.2 million $\mathrm{m}^{3}$ (1000 AF) of water for CSIP supply during periods of drought [13]. PWM adds to this drought reserve during normal and wet years so that during subsequent dry years, PWM can treat and inject less than 4.3 million $\mathrm{m}^{3} / \mathrm{y}$ ( $3500 \mathrm{AFY}$ ), leaving the banked difference available for CSIP while still providing the full amount for potable use.

Close conjunction between the integrated CSIP, PWM, and RUWAP projects provides benefits of shared infrastructure and costs, but this overlap can also lead to competition as expansion efforts draw from the same available source waters and system capacities. Yet each project is operating under different constraints and goals with different demand schedules throughout the year. Moreover, project overlaps can create mutual opportunities, since multiple projects may benefit from an improvement (e.g., storage) that is only directly available to one project subsystem. This underscores the importance of integrated planning, both to identify opportunities for collaboration and to maintain mutually beneficial partnerships.

\subsection{Future Adaptability and Expansion}

A shared feature of Monterey's water reuse programs is that they include expansion plans to meet growing demand. This proactive planning supports sustained project benefits and prepares expansion efforts to move quickly when funding, public sentiment, or regulatory support is available. Proposed expansions were introduced at various stages during and following the initial project design. However, as discussed below, expansion efforts must also consider the capacity of conveyance, storage, and injection systems, as well as source water availability and user demand.

\subsubsection{Pure Water Monterey Expansion}

In 2017, just one year after the State Water Resources Control Board had approved the Final Engineering Report for the original PWM project, the California Public Utilities Commission (CPUC) initiated a discussion about whether PWM could be expanded to help meet the court order for reduced taking of Carmel River water [33]. In 2019, M1W advanced development of the PWM Expansion with a Draft Supplemental Environmental Impact Report [48]. The PWM Expansion project was proposed as a backup to CalAm's CPUC-approved desalination plant so that if litigation or other delays prevented the desalination project from feasibly operating a plant before the December 2021 target to comply with the cease and desist order, then the PWM Expansion project could be quickly implemented instead [48].

The proposed PWM Expansion would treat an additional 2.8 million $\mathrm{m}^{3} / \mathrm{y}$ (2250 AFY) for groundwater replenishment, increasing potable reuse from 4.3 million $\mathrm{m}^{3} / \mathrm{y}$ ( $3500 \mathrm{AFY}$ ) to 7.1 million $\mathrm{m}^{3} / \mathrm{y}$ (5750 AFY) on average [48]. The Supplemental Environmental Impact Report evaluated a proposed increase in the AWPF treatment capacity, as well as construction of additional and modified injection, extraction, monitoring, and conveyance facilities [48]. PWM Expansion would utilize existing M1W water sources and not require new sources or increased diversion capacity [48]. The additional volume needed for PWM Expansion would come mostly from winter flows of wastewater, ag wash, and stormwater; as illustrated in Figure 7, these winter flows are not currently recycled when CSIP demand is low [47].

\subsubsection{Castroville Seawater Intrusion Project Expansion}

The Salinas Valley Basin Groundwater Sustainability Agency has presented potential projects to optimize and expand CSIP operations as a major part of the Groundwater Sustainability Plan developed under California's Sustainable Groundwater Management Act [21]. Among nine priority projects 
selected for their cost-effectiveness, feasibility, reliability, and stakeholder acceptance, four are focused on improvements to the CSIP system. These projects are summarized in Table 1. The Groundwater Sustainability Plan was approved in 2020, so the proposed CSIP improvements are in relatively early stages of planning compared to the proposed PWM Expansion [21]. Still, the estimated water costs per unit volume are low compared to potable reuse or desalination.

Table 1. Salinas Valley Basin Groundwater Sustainability Agency ranked priority projects for improving the Castroville Seawater Intrusion Project, CSIP (data from [21]).

\begin{tabular}{|c|c|c|c|c|}
\hline Priority Ranking & Proposed Project & Description & $\begin{array}{c}\text { Est. Yield } \\
\mathrm{m}^{3} / \mathbf{y} \\
\text { (AFY) }\end{array}$ & $\begin{array}{c}\text { Est. Cost } \\
\$ / \mathrm{m}^{3} \\
(\$ / A F)\end{array}$ \\
\hline \#2 & $\begin{array}{l}\text { Optimize CSIP } \\
\text { Operations }\end{array}$ & $\begin{array}{l}\text { Maximize use of available water } \\
\text { within distribution constraints }\end{array}$ & $\begin{array}{c}6.8 \times 10^{6} \\
(5500)\end{array}$ & $\begin{array}{l}\$ 0.22 \\
(\$ 270)\end{array}$ \\
\hline$\# 3$ & Modify RTP & $\begin{array}{l}\text { Decrease minimum SVRP capacity } \\
\text { to allow production for winter } \\
\text { irrigation demand }\end{array}$ & $\begin{array}{c}1.4 \times 10^{6} \\
(1100)\end{array}$ & $\begin{array}{l}\$ 0.07 \\
(\$ 90)\end{array}$ \\
\hline$\# 4$ & Expand CSIP Area & $\begin{array}{c}\text { Expand distribution by } 14 \mathrm{~km}^{2} \\
\text { (3500 acres) }\end{array}$ & $\begin{array}{c}12 \times 10^{6} \\
(9900)\end{array}$ & $\begin{array}{l}\$ 0.51 \\
(\$ 630)\end{array}$ \\
\hline \#5 & $\begin{array}{l}\text { Optimize Salinas River } \\
\text { Diversion Facility }\end{array}$ & $\begin{array}{l}\text { Maximize diversion from the } \\
\text { Salinas River }\end{array}$ & $\begin{array}{l}14 \times 10^{6} \\
(11,600)\end{array}$ & $\begin{array}{l}\$ 0.18 \\
(\$ 220)\end{array}$ \\
\hline
\end{tabular}

\subsubsection{Regional Urban Water Augmentation Project Phase 2}

Phase 1 of the RUWAP project supplies the Marina Coast Water District with 0.7 million $\mathrm{m}^{3} / \mathrm{y}$ (600 AFY) of recycled water, yet this amount is less than the full amount of 2.6 million $\mathrm{m}^{3} / \mathrm{y}$ (2100 AFY) to which the MCWD is entitled based on its wastewater contribution to the RTP [42]. To utilize a greater portion of its allocated right, the MCWD has planned a Phase 2 expansion for 2025 [42]. In Phase 2, advanced treated recycled water delivery to RUWAP will increase to 1.8 million $\mathrm{m}^{3} / \mathrm{y}$ (1427 AFY) with an expanded distribution network [49,50]. The MCWD is planning for expanded RUWAP service by requiring new developments to install separate recycled water pipelines for irrigating open spaces [42].

A summary of major reuse projects and their proposed expansions is provided in Table 2.

\subsection{Challenges and Path Forward}

\subsubsection{Winter Storage to Meet Summer Demand}

As expansion efforts utilize a greater portion of available source water, resolving mismatched timing between source water availability and user demand becomes increasingly important to maximize recycled water use. On the Monterey Peninsula, recycled water use is presently limited not by the total amount but by the timing of available water. Summer irrigation relies on groundwater and surface water contributions to supplement available recycled water, yet in the winter millions of cubic meters of potential source water goes unused. With the completion of the PWM project, the Monterey region is already poised to take advantage of diverse source waters, but opportunities remain to more fully utilize new source waters and off-season flows. Storage provides a critical link between misaligned water supply and demand. Storage prior to treatment might target the capture of source water flows exceeding treatment capacity, while storage of finished water could target the gap between the treatment capacity and peak use demand. In storing winter water for summer use, the scale of the storage must be large enough to provide a meaningful quantity of water. Seasonal storage on the order of millions of cubic meters (hundreds or thousands of acre-feet) would help the CSIP, PWM, and RUWAP projects grow to continue to meet water demand in the future. 
Table 2. Summary of reuse projects and proposed expansions.

\begin{tabular}{|c|c|c|c|c|c|c|c|c|c|}
\hline \multicolumn{2}{|c|}{ Program } & Agency & Source Water & Treatment & $\begin{array}{l}\text { Production } \\
\mathrm{m}^{3} / \mathrm{y} \text { (AFY) }\end{array}$ & Use & $\begin{array}{l}\text { Storage } \\
\text { Volume } \\
\mathrm{m}^{3} \text { (AF) }\end{array}$ & Storage Location & Interfaces \\
\hline \multirow{2}{*}{$\begin{array}{c}\text { CSIP } \\
{[13,21,30,32,43,51]}\end{array}$} & $\begin{array}{c}\text { Castroville Seawater } \\
\text { Intrusion Project }\end{array}$ & \multirow{2}{*}{$\begin{array}{c}\text { M1W, } \\
\text { MCWRA }\end{array}$} & \multirow{6}{*}{$\begin{array}{l}\text { Wastewater } \\
\text { Ag wash } \\
\text { Urban runoff } \\
\text { Rec. Ditch } \\
\text { Blanco Drain }\end{array}$} & \multirow{2}{*}{ Tertiary } & $\begin{array}{l}24.1 \times 10^{6} \\
(19,500)^{1} \\
\end{array}$ & \multirow{2}{*}{$\begin{array}{l}\text { Agricultural } \\
\text { irrigation }\end{array}$} & $\begin{array}{c}0.1 \times 10^{6} \\
(80)\end{array}$ & RTP pond & \multirow{2}{*}{$\begin{array}{l}\text { RTP, source water (all) } \\
\text { Drought reserve } \\
\text { (PWM) }\end{array}$} \\
\hline & Expansion & & & & $\begin{array}{l}12.2 \times 10^{6} \\
(9900)\end{array}$ & & $\begin{array}{c}4-9 \times 10^{6} \\
(3000-7000)\end{array}$ & $\begin{array}{l}\text { Armstrong Ranch } \\
\text { subsurface }\end{array}$ & \\
\hline \multirow{2}{*}{$\begin{array}{c}\text { PWM } \\
{[13,39,44,47,48]}\end{array}$} & Pure Water Monterey & \multirow{2}{*}{$\begin{array}{c}\text { M1W, } \\
\text { MPWMD }\end{array}$} & & \multirow{4}{*}{ Advanced } & $\begin{array}{c}4.3 \times 10^{6} \\
(3500)\end{array}$ & \multirow{2}{*}{$\begin{array}{l}\text { Groundwater } \\
\text { replenishment }\end{array}$} & $\begin{array}{c}1.3 \times 10^{6} \\
(1065) \\
+\end{array}$ & \multirow{2}{*}{$\begin{array}{l}\text { SIWTF ponds, } \\
\text { Blackhorse Reservoir }\end{array}$} & \multirow{2}{*}{$\begin{array}{l}\text { RTP, source water (all) } \\
\text { Drought reserve } \\
\text { (CSIP) } \\
\text { Pipeline (RUWAP) }\end{array}$} \\
\hline & Expansion & & & & $\begin{array}{l}2.8 \times 10^{6} \\
(2250)\end{array}$ & & $\begin{array}{c}7000 \\
(6)\end{array}$ & & \\
\hline \multirow{2}{*}{$\begin{array}{c}\text { RUWAP } \\
{[13,42,47,48]}\end{array}$} & $\begin{array}{l}\text { Regional Urban Water } \\
\text { Augmentation Project }\end{array}$ & \multirow{2}{*}{ MCWD, M1W } & & & $\begin{array}{l}0.7 \times 10^{6} \\
(600)\end{array}$ & \multirow{2}{*}{$\begin{array}{l}\text { Urban } \\
\text { irrigation }\end{array}$} & \multirow{2}{*}{$\begin{array}{c}7000 \\
(6)\end{array}$} & \multirow{2}{*}{ Blackhorse Reservoir } & \multirow{2}{*}{$\begin{array}{l}\text { RTP, source water (all) } \\
\text { Pipeline (PWM) }\end{array}$} \\
\hline & Phase 2 & & & & $\begin{array}{c}1.0 \times 10^{6} \\
(827)\end{array}$ & & & & \\
\hline
\end{tabular}

${ }^{1}$ This amount includes supplemental groundwater and Salinas River contributions. Recycled water contributions average $15.4 \mathrm{million} \mathrm{m}^{3} / \mathrm{y}(12,500 \mathrm{AFY})$ [30]. 
Currently, the tertiary treatment facility produces recycled water for CSIP during the summer months but shuts down during winter months when irrigation demand is less than the $19,000 \mathrm{~m}^{3} / \mathrm{d}$ (5 mgd) minimum flow for tertiary treatment operations [21]. Meanwhile, 7-10 million $\mathrm{m}^{3}$ (6000-8000 AF) of potential source water is discharged each winter through the ocean outfall [47]. Seasonal-scale storage within the CSIP system could extend operation of the tertiary treatment plant, facilitating reuse of winter outfall discharge and producing additional irrigation supply for the growing season. Increased storage would also mitigate drought risk, promoting continued investment in high-value crops [52].

Adjacent to the RTP, there exists an opportunity for subsurface storage of 4-9 million $\mathrm{m}^{3}$ (3000-7000 AF) of water within the $0.9 \mathrm{~km}^{2}$ (220 acre) Armstrong Ranch parcel [51]. This location has previously been identified as potential storage for tertiary treated water prior to CSIP distribution, but a storage project is not actively being pursued. Initial groundwater modeling indicates that nonpotable water stored in the Armstrong Ranch perched aquifer would be sufficiently isolated by the underlying aquitard and a constructed lateral hydraulic barrier [51]. However, additional regulatory guidance is needed to clarify requirements for subsurface storage, distinguished from wastewater disposal and from potable recharge (Appendix A.2.3). Utilizing the subsurface storage at Armstrong Ranch would offer a substantial increase in storage beyond the existing 0.1 million $\mathrm{m}^{3}$ ( $80 \mathrm{AF}$ ) pond at the RTP. The additional water made available to CSIP through this storage could facilitate the expansion of CSIP's service area, further reducing regional reliance on groundwater wells and the Salinas River to meet irrigation demand.

Increasing seasonal storage offers both water supply and pollution control benefits. With the addition of novel sources, Monterey's present recycled water projects include production for CSIP (18.1 million $\mathrm{m}^{3} / \mathrm{y} ; 14,700 \mathrm{AFY}$ ), PWM (4.3 million $\left.\mathrm{m}^{3} / \mathrm{y} ; 3500 \mathrm{AFY}\right)$, and RUWAP (0.7 million $\mathrm{m}^{3} / \mathrm{y}$; $600 \mathrm{AFY}$ [44,48]. If storage options are developed to capture off-season flows of 11.5 million $\mathrm{m}^{3} / \mathrm{y}$ (9300 AFY) of available source water [44], then recycled water supply could be expanded by up to nearly $50 \%$, depending on the balance of tertiary and advanced treatment. Distributing additional recycled water reduces discharges of secondary effluent to Monterey Bay National Marine Sanctuary, which benefits the adjacent marine environment in addition to providing potable water offset from urban and rural recycled water use. Although the secondary effluent discharged to the sanctuary complies with its National Pollutant Discharge Elimination System permit [53], increased capture of secondary effluent would support water quality improvements including reduced nutrient loading. When recycled, nutrients in the tertiary effluent add value as fertilizer for CSIP growers [54].

\subsubsection{Funding and Proposition 218}

Successful management of peri-urban water supplies depends on effective and equitable funding strategies. In California, water revenues must comply with Proposition 218 (“Prop 218”), which supports accountability of local governments by requiring voter approval of taxes and fees [55]. Particularly relevant to water supply are Prop 218's requirements that fees charged to a parcel "shall not exceed the proportional cost of the service attributable to the parcel," and that any fees must apply to services "actually used by, or immediately available to, the owner of the property in question" [56].

These quoted passages provide important guidance on funding strategies for California water supplies, as evidenced by the recent case of Capistrano Taxpayers Association, Inc. v. City of San Juan Capistrano [57]. For San Juan Capistrano, funding strategies included tiered water rates to promote conservation, as well recycled water charges distributed among all ratepayers to subsidize costs for recycled water users. In 2013, the Orange County Superior Court ruled that the city's tiered water rates violated Prop 218's proportionality requirement because these rates were not justified by the actual incremental costs of higher consumption. It further ruled that per the immediate use requirement, costs associated with recycled water projects could only be distributed to ratepayers who directly received the recycled water. In 2015, the Fourth District Court of Appeals reversed this latter ruling, 
concluding that water supply is a single service immediately available to all customers, so there is no Prop 218 violation in distributing recycled water costs among all ratepayers [58].

The precedent set by the case is that recycled water costs can be shared among all water users to avoid prohibitive costs to the recycled water users. Second, tiered water rates or conservation charges must be justified by the actual costs incurred in supplying more expensive water to meet excessive consumption. Since a recycled water project might be necessary only because of high demand, it remains unclear whether Prop 218 allows recycled water costs to be allocated to customers whose low consumption levels would not necessitate more expensive sources such as recycled water [59].

In Monterey County, capital and operational costs associated with the PWM project are funded through a Water Supply Charge assessed to all users of CalAm's main water system [60]. This charge was enacted in 2012 through a regulated procedure including notice to customers, a public hearing, and a count of written objections [61]. In Monterey County, recycled water produced through PWM enters the groundwater supply that serves all customers. This lends intuitive support to the legal interpretation that recycled water costs are simply one component of a single water service and thus can be distributed to all ratepayers as beneficiaries. However, Monterey may have to waive its Water Supply Charge for low-use customers if it is ruled for San Juan Capistrano that more expensive alternative water sources are a proportionality consideration.

As with PWM, CSIP costs are distributed broadly among beneficiaries. M1W also leveraged considerable federal and state funding to finance the large initial costs of developing a recycled water program. Federal Bureau of Reclamation loans financed about $70 \%$ of the capital costs for the SVRP tertiary treatment and CSIP distribution projects [29]. Ongoing debt service and operational expenses for these two projects are funded by water delivery and service fees from customers receiving recycled water, as well as parcel-based benefits assessments from elsewhere in the Salinas Valley [62]. Based on 2020-2021 rates, CSIP customers pay delivery and acreage fees, $\$ 0.07 / \mathrm{m}^{3}(\$ 81 / \mathrm{AF})$, and $\$ 0.08 / \mathrm{m}^{2}$ (\$308/acre), while other parcels pay $\$ 0-0.02 / \mathrm{m}^{2}$ (\$0-94/acre), depending on land use and location within the valley [62]. Assuming an annual delivery of 24.1 million $\mathrm{m}^{3} / \mathrm{y}(19,500 \mathrm{AF})$ to the $49 \mathrm{~km}^{2}$ (12,000 acres) receiving CSIP water, the combined delivery and acreage fees result in an average cost to CSIP growers of approximately $\$ 0.22 / \mathrm{m}^{3}$ ( $\$ 271 / \mathrm{AF}$; authors' calculation).

\subsubsection{Debating Desalination}

Although the Monterey region has demonstrated great progress in leveraging collaborative water projects to satisfy agricultural and urban needs, the future direction of the region's water supply is currently under debate. Excluding unlawful extractions from the Carmel River and Seaside Basin, the Peninsula's available water supply of 11.7 million $\mathrm{m}^{3} / \mathrm{y}$ (9450 AFY) is insufficient to meet long-term needs [48]. Community leaders disagree on whether desalination or expanded reuse offers a better water supply solution, and uncertainty surrounding future demand forms a critical part of this debate. In a 2018 decision, the CPUC supported a water demand projection of 17.3 million $\mathrm{m}^{3} / \mathrm{y}$ (14,000 AFY) [63], but Stoldt [64] argues that 13.4-15.2 million $\mathrm{m}^{3} / \mathrm{y}(10,900-12,300 \mathrm{AFY})$ is a more appropriate estimate in light of additional demand data from recent years.

To satisfy future water demand, CalAm has proposed the Monterey Peninsula Water Supply Project (MPWSP) featuring a desalination plant that would produce up to 7.7 million $\mathrm{m}^{3} / \mathrm{y}$ (6250 AFY) of potable water $[36,48,63]$. Alternatively, M1W has proposed the PWM Expansion, which would produce 2.8 million $\mathrm{m}^{3} / \mathrm{y}$ (2250 AFY) to meet demand for at least the next decade, thereby delaying or forestalling the higher costs and energy use associated with desalination $[47,64,65]$. The projected total water supply associated with each proposed project is compared in Figure 8. Since the proposed desalination project would produce more water than the PWM Expansion, the amount and timing of future demand is critical in evaluating the two projects. Table 3 compares estimated cost and energy requirements, highlighting substantial differences between seawater desalination and indirect potable reuse with groundwater recharge. If future water demand is less than projected and the proposed 
desalination plant operates at lower capacity than expected, the cost and energy requirements per unit volume of desalinated water could be even greater than predicted [66].

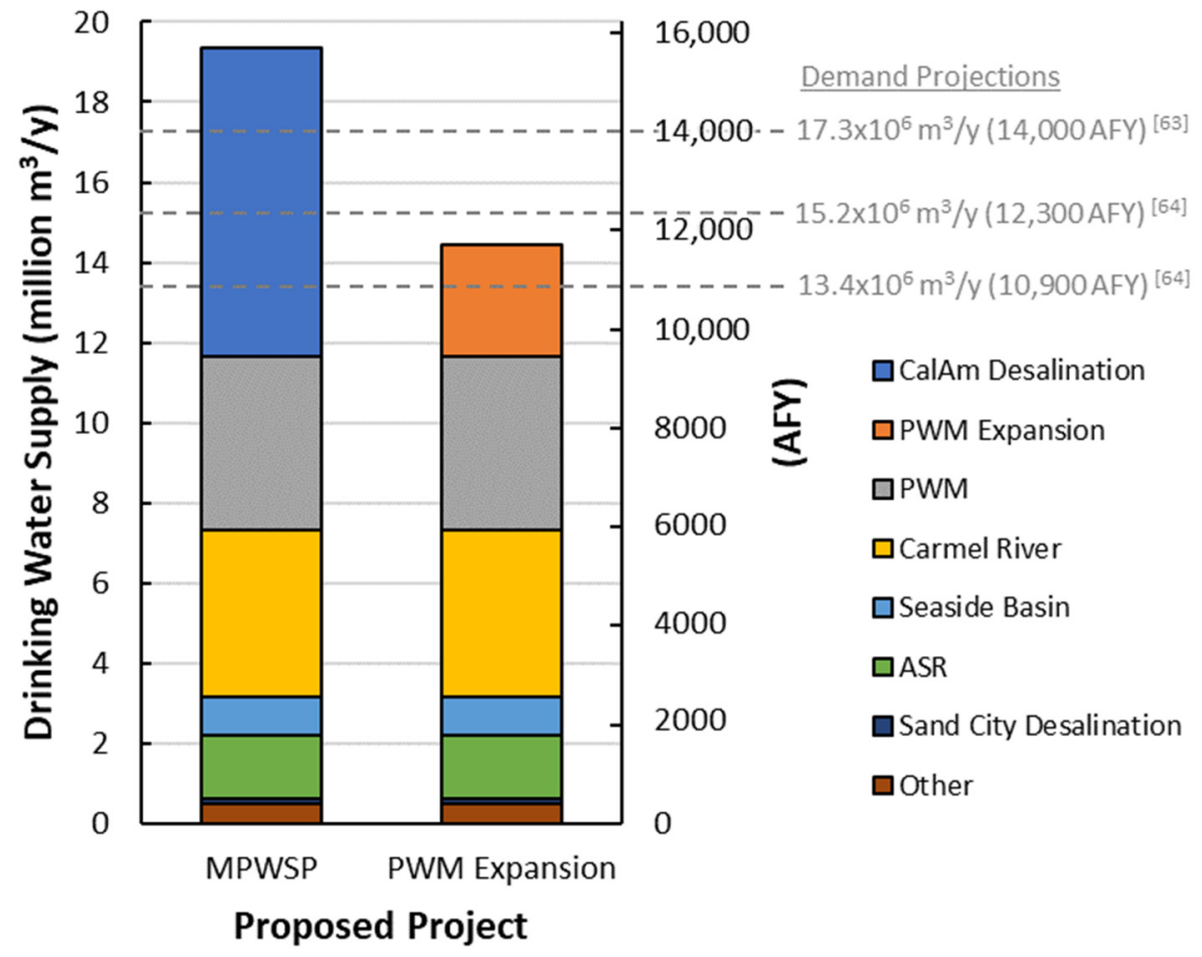

Figure 8. Total Monterey Peninsula water supply under each proposed project scenario (data from $[48,63,64])$.

Table 3. Comparison of yield, cost, and energy for the proposed Monterey Peninsula Water Supply Project's (MPWSP) seawater desalination plant and Pure Water Monterey's (PWM) groundwater replenishment potable reuse project.

\begin{tabular}{ccc}
\hline Project & MPWSP Desalination & PWM Expansion \\
\hline Yield, & $7.7 \times 10^{6}$ & $2.8 \times 10^{6}$ \\
$\mathrm{~m}^{3} / \mathrm{y}(\mathrm{AFY})$ & $(6250)[48]$ & $(2250)[48]$ \\
\hline $\begin{array}{c}\text { Cost, } \\
\$ / \mathrm{m}^{3}(\$ / \mathrm{AF})\end{array}$ & $\begin{array}{c}\$ 4.90-6.50 \\
(\$ 6000-8000)[65]\end{array}$ & $\begin{array}{c}\$ 1.70 \\
(2100)[65]\end{array}$ \\
\hline Energy Demand, & 6.7 & 2.1 \\
$\mathrm{kWh} / \mathrm{m}^{3}(\mathrm{MWh} / \mathrm{AF})$ & $(8.3)[36]$ & $(2.6)[48]$ \\
\hline
\end{tabular}

While desalination is CalAm's preferred plan with PWM Expansion as a backup, the path forward for desalination is not settled. The CPUC approved CalAm's desalination project in 2018 [63], but the City of Marina Planning Commission denied the required coastal development permit [67]. CalAm appealed to the California Coastal Commission, but the ensuing staff report recommended that the Coastal Commission deny the permit [65]. In September 2020, one day before the scheduled Coastal Commission vote, CalAm withdrew its permit application [68], intending to reapply within several months after discussing environmental justice and cost concerns with residents [69]. CalAm refiled its application in November 2020, but the Coastal Commission has requested additional information to complete the application, which may further delay a decision [70].

At the time the CPUC was evaluating the desalination project, the PWM Expansion project had just been conceived and was not yet adequately formed to be a feasible alternative [65]. Since then, the PWM Expansion project has advanced to a final supplemental environmental impact report, though a significant obstacle to its approval is that CalAm must agree to purchase the finished water [71]. Desalination supporters have criticized the PWM Expansion for failing to meet the Peninsula's full 
projected need and for not contributing added diversity to the region's water portfolio, as desalination would [72]. Nonetheless, CalAm is under pressure to comply with the Carmel River cease and desist order, so now that a possible alternative to desalination has been identified, CalAm may be forced to agree to this option if the desalination project continues to experience delays. At this time, neither the desalination project nor the PWM Expansion could be completed before the December 2021 deadline, but the respective project schedules may be an important consideration for minimizing noncompliance or meeting an extended deadline [36,47]. It is also possible that CalAm could temporarily satisfy the cease and desist order with careful management of existing sources, though additional supply is necessary to meet growing demand and to ensure reliability [73].

As evidenced by the recommendation of the California Coastal Commission's staff report to deny the desalination project, litigation surrounding social and environmental impacts will likely continue to interfere with timely construction of a desalination plant. A major point of opposition to the desalination project is the threat to local groundwater posed by its intake wells [33]. The project design uses a novel technology, slant wells, which slope downward under the ocean bed, extracting seawater along their length from the subsurface [74]. The subsurface intake minimizes impact to marine life and provides filtration. Ideally, well heads would be positioned near the shore so that slant wells extending seaward would draw water exclusively from beneath the ocean to avoid exacerbating seawater intrusion [74]. At CalAm's selected extraction site near the City of Marina, however, construction near the coast is blocked by endangered snowy plover habitat, protected dunes, and projected coastal erosion [74]. Consequently, the proposed wells are situated largely beneath dry land, with only small portions (0-78 m; 0-257 ft) of the total well lengths (209-296 m; 685-970 ft) extending offshore (Figure 9) [36].

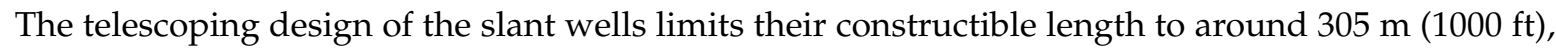
making it infeasible to simply extend the well lengths to overcome the required setback distance [75].

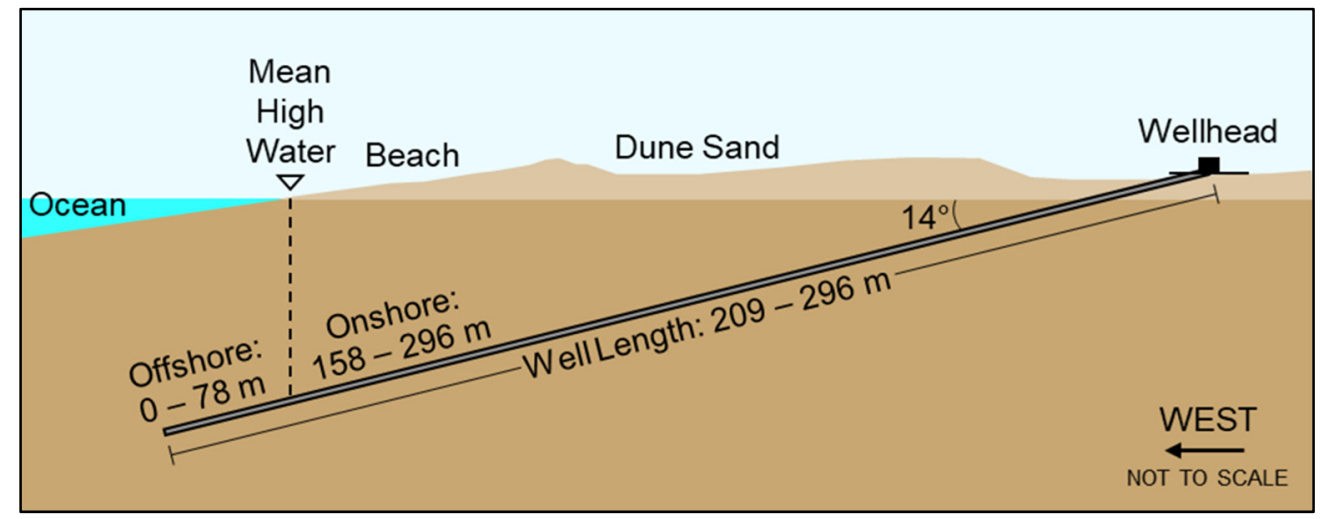

Figure 9. Proposed slant well profile with onshore and offshore well lengths (adapted from [36]).

CalAm maintains that its slant wells would extract seawater and brackish water only, with no impact to local potable groundwater, based on superposition modeling with the MODFLOW-based North Marina Groundwater Model [36]. The City of Marina disagrees with CalAm's conclusion, citing a study by Goebel et al. [76] that used airborne electromagnetic sensing to reveal a more nuanced, connected patchwork of brackish and freshwater zones existing within the intruded boundary used by CalAm's analysis [77]. The contested risk to local aquifers contributed to the Marina Planning Commission's decision to deny CalAm's coastal development permit [67], and it also prompts environmental justice concerns since the City of Marina lies outside CalAm's service area where project benefits would be experienced [66].

\subsubsection{Debating Public versus Private Water Supply}

Community opposition to CalAm's desalination project does not end at Marina's city limits. Monterey Peninsula residents have spoken out against the higher cost and energy demand of employing 
desalination before other water supply options have been fully tapped [78]. Residents have expressed concerns that CalAm as a private corporation is not properly accountable to the public and that its for-profit organization presents a conflict of interest with serving the best interests of the community [66]. Since 1995, CalAm ratepayers have borne over $\$ 34$ million in costs from the company's failed water supply projects, as well as the cumulative harm from excessive withdrawals from the Seaside Basin and Carmel River [79]. Frustrated by this dynamic, in 2018 Monterey County voters approved Measure $\mathrm{J}$, directing MPWMD to conduct a feasibility study for public acquisition of CalAm's Monterey water system [80]. The ensuing feasibility study concluded that acquisition would be economically feasible, estimating net present savings of \$213-267 million over the next 20 years [81]. The MPWMD published a draft environmental impact report in June 2020, which concluded that public acquisition would have no significant and unavoidable environmental impacts [82].

The broader controversy between public and private water supply further complicates the debate between desalination and PWM Expansion, creating multiple levels of uncertainty for the future of water management in the Monterey region. Delays faced by CalAm's approved desalination project highlight the influence of community involvement in shaping water management outcomes. Public response against CalAm has been propelled by the work of community action groups, notably Citizens for Just Water opposing the intake wells in Marina [66] and Public Water Now introducing Measure J [83]. In contrast, the PWM Expansion water reuse project is supported by residents who oppose CalAm's desalination project, and the PWM Expansion builds on the momentum of the recently completed original PWM project [33]. M1W cultivates this public support with outreach efforts including a mailing list [84], plant tours [85], and a recently updated website [86] containing both high-level project overviews and detailed engineering reports.

\subsubsection{Planning Supply for Uncertain Demand}

With layered uncertainty characterizing future water supply and demand on the Monterey Peninsula, more information is needed before the region can confidently plan a permanent water solution. Alternative water supplies require greater cost, energy, and emissions compared to conventional surface and groundwater sources [87], so planning efforts must consider the best balance between conventional and alternative supplies, in addition to the right portfolio of alternative supplies [88]. Uncertainty surrounding Monterey's water demand stems partly from the recent decline in water demand within CalAm's service area, which fell from 16.3 million m³/y (13,200 AFY) in 2009 [36] to 11.4 million $\mathrm{m}^{3} / \mathrm{y}$ (9200 AFY) in 2019 [89]. An increase in water supply can facilitate unforeseen additional demand [90], though the magnitude and timing of this rebound is unclear. Conservation achieved through behavioral changes and emergency restrictions tends to decay over time [91], while structural elements like low-flow appliances would be maintained.

Already, the availability of recycled water has resulted in reduced demand for desalinated water, as CalAm's proposed desalination plant was scaled down from $36,000 \mathrm{~m}^{3} / \mathrm{d}(9.6 \mathrm{mgd})$ to $24,000 \mathrm{~m}^{3} / \mathrm{d}$ $(6.4 \mathrm{mgd})$ to accommodate available water from the original PWM project [36]. The PWM Expansion could function similarly by further reducing required desalination and by postponing decisions about desalination until the need is more immediate and, thus, better understood. While M1W predicted in 2018 that the PWM Expansion could provide adequate water supply for 5-15 years [47], more recent projections extend this interval to as much as 30 years [64,65,92], underscoring the uncertainty associated with future water demand on the Peninsula (Figure 10). Trends in water demand observed over the next several years would support more informed planning of a desalination project, thus providing informational benefit in addition to the interim cost and energy savings of recycled water use. 


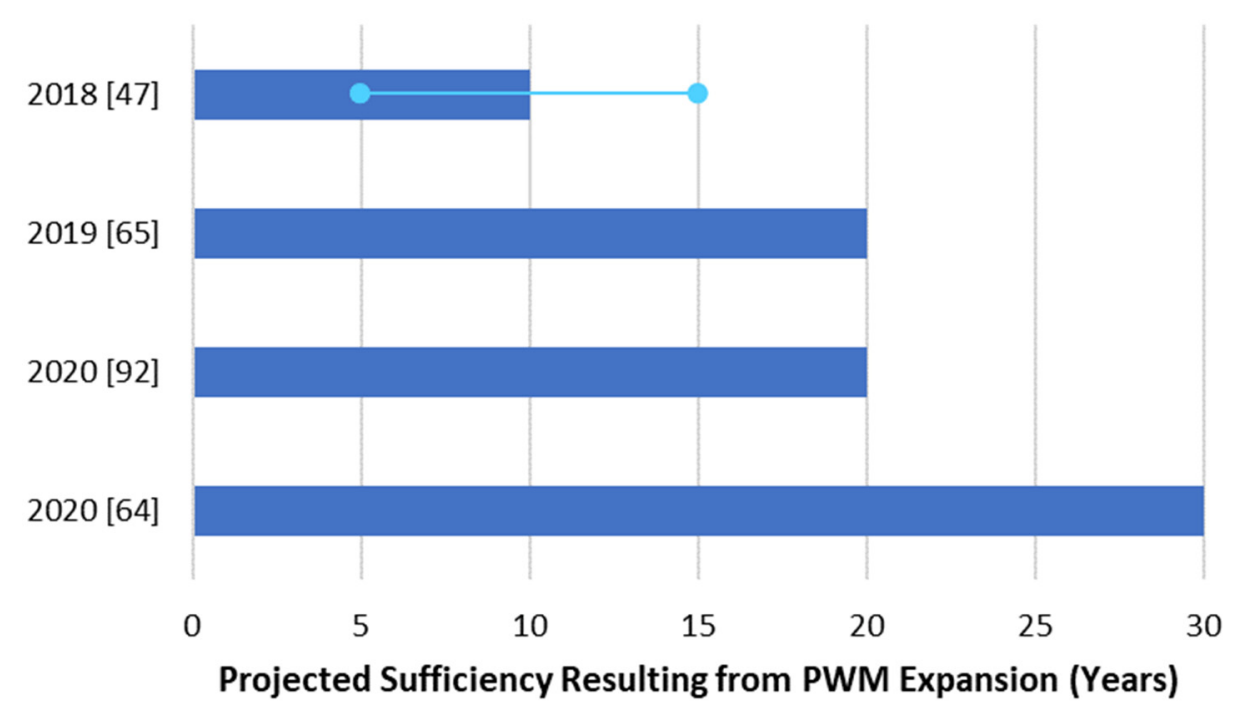

Figure 10. Estimates of how long the Pure Water Monterey Expansion could satisfy water demand on the Monterey Peninsula. Recent estimates reveal significant uncertainty in projected demand.

\subsection{Integrated Water Management}

Water resource managers in other regions can benefit from the lessons of successes and challenges in Monterey's integrated water management program. One such success is the way in which Monterey leverages its water supply stressors to elicit change. Costs, regulatory hurdles, and other barriers to water supply projects are unavoidable, so the justification for these projects must be communicated in equally concrete terms. Monterey's recycled water programs were motivated by tangible effects of resource scarcity and climate change, including seawater intrusion, state restrictions on conventional water sources, and the effects of the 2012-2016 drought. Since public response is linked to awareness of water supply risks [93], water resource management should focus on workable solutions to local needs to build support for alternative water supply projects.

The success of Monterey's water program is found not only in its novel water supplies but also in its strong regional partnerships. In California, integrated water management efforts must navigate numerous and complex water management institutions [94], and Monterey models a pathway to accomplish this. Water managers and stakeholder groups working together and building trust can define potential advantages of regional planning, including cost savings from shared infrastructure, equitable distribution of risks and benefits, flexibility matching supply and demand, and the availability of state and federal funding. Regional collaborations can internalize externalities and broaden participation in water solutions. In practice, this could mean distributing recycled water costs to beneficiaries beyond direct recipients, and this could make the difference between feasible and prohibitive costs.

Seasonal mismatch between water availability and demand represents a key challenge to integrated water management, particularly to programs serving agricultural and urban irrigation needs. Regional partnerships link supply and demand across space, but additional capital improvements are needed to make this connection across time. This study has identified seasonal storage as a promising solution to reduce contaminant loading and maximize water supplies. However, regulatory guidance needs to be developed to help water managers implement the subsurface projects that would provide cost-effective recycled water storage at this scale.

Another critical challenge to integrated water management is planning effectively under uncertainty. Sustainability objectives encourage long-term planning, but planning efforts must also consider the limitations of present data and the tradeoffs between present and future costs, benefits, and risks. In Monterey, the debate between desalination and recycled water expansion shows that these tradeoffs are not easily resolved. To strengthen decision making under uncertainty, water managers should delineate between scientific data and value judgments [95], and they should engage varied 
stakeholders to better understand value preferences. Adaptive solutions such as phased or expandable projects can lay the groundwork to meet future needs without requiring a large present investment.

\section{Conclusions}

This study has looked to Monterey County as an exemplar of one water management at the agricultural-urban interface. Faced with growing threats to its conventional water supplies, the Monterey/Salinas region responded by developing an innovative recycled water network to serve the region's diverse water needs. Monterey's one water management story offers valuable lessons for cultivating integrated water solutions, and it highlights critical challenges that remain.

Monterey's experience demonstrates that a regional focus creates opportunities for one water management. Regional partnerships strengthen integrated planning efforts by dissolving traditional water management silos, internalizing costs and benefits of alternative water supplies, and encompassing a larger body of potential sources and demands. Monterey's recycled water network combines urban and agricultural sources to meet both urban and agricultural demands, which results in greater flexibility and economy in serving both constituents. In developing this network, Monterey pioneered the use of tertiary recycled water to irrigate freshly edible food crops and the use of novel source waters to grow and diversify the region's recycled water supply. M1W and partnering agencies built confidence in these innovations through pilot testing and by framing these solutions in the context of local needs. Monterey's story highlights the importance of community engagement to water management planning. CalAm's proposed desalination project received high-level CPUC approval but has since stalled as community groups mobilize around environmental justice and accountability. Meanwhile, growing support from the community has transformed the PWM Expansion backup option into a serious contender for the Peninsula's future water supply.

A critical challenge that remains for Monterey and other peri-urban communities is the seasonal mismatch between recycled water supply and demand, especially for irrigation. Without adequate storage, investments in recycled sources and treatment to serve agricultural users can be utilized only during a fraction of the year. Opportunities for seasonal scale storage exist, but Monterey and other communities considering reservoir or subsurface storage of recycled water would benefit from additional regulatory guidance addressing recycled water storage as distinct from effluent discharge or indirect potable reuse.

The controversy between public and private water supply complicates the debate between desalination and recycled water expansion in the Monterey region. To build a future for communities and industries, water-stressed regions must plan for the long-term sustainability of their water supplies, though they must also consider the tradeoffs of incurring the cost and energy burden of more intensive water supplies before there is certain need. Monterey's experience suggests that community values and future adaptability can help water supply planners navigate this uncertainty when making decisions about water infrastructure investments. In Monterey looking forward, continued evaluation of regional water demand would support more informed planning and justification for a desalination project. Meanwhile, operational data on the PWM system would add to this discussion by highlighting the cost and energy savings for recycled water and other benefits.

Author Contributions: Conceptualization, B.C.G. and R.G.L.; formal analysis, B.C.G. and R.G.L.; resources, P.A.S. and N.A.; writing-original draft preparation, B.C.G. and N.A.; writing-review and editing, B.C.G., R.G.L., and P.A.S.; visualization, B.C.G. and R.G.L.; supervision, R.G.L.; funding acquisition, B.C.G. and R.G.L. All authors have read and agreed to the published version of the manuscript.

Funding: This work was supported by the U.S. National Science Foundation Engineering Research Center for Re-Inventing the Nation's Urban Water Infrastructure, ReNUWIt (NSF ERC 1028968), and NSF INFEWS/T1 (NSF 1739676). B.C.G. was supported by the NSF Graduate Research Fellowship (DGE 1656518) and by a graduate fellowship award from Knight-Hennessy Scholars at Stanford University.

Conflicts of Interest: The authors declare no conflict of interest. 


\section{Appendix A}

The water sources introduced by the PWM project represent a major innovation in water reuse. Together, the new sources from ag wash, Blanco Drain, Reclamation Ditch, and Salinas urban stormwater runoff offer not only additional volume for reuse, but also a more diverse water supply portfolio. A description of these novel water sources is provided below, along with a discussion of treatment and storage considerations.

\section{Appendix A.1. Source Waters}

\section{Appendix A.1.1. Blanco Drain}

Blanco Drain collects agricultural surface and tile drainage and stormwater runoff from approximately $26 \mathrm{~km}^{2}$ (6400 acres) located to the east of Salinas [13]. Blanco Drain is listed as impaired for pesticides, nitrate, and toxicity under the Clean Water Act Section 303(d) [96]. Diversion of up to 3.7 million $\mathrm{m}^{3} / \mathrm{y}$ (3000 AFY) is permitted, provided that minimum ecological flows are maintained [97]. During a typical normal or wet year, M1W estimates that up to 3.3 million $\mathrm{m}^{3} / \mathrm{y}$ (2670 AFY) would be available for diversion [71]. Presently, Blanco Drain contributes approximately 2.3 million $\mathrm{m}^{3} / \mathrm{y}$ (1870 AFY), or 37\%, of the PWM source water, supplied during the months of March through October [71].

Appendix A.1.2. Reclamation Ditch

The Reclamation Ditch receives agricultural drainage and natural and urban runoff flows from a $407 \mathrm{~km}^{2}\left(157 \mathrm{mi}^{2}\right)$ drainage network, including most of the city of Salinas [13]. The Reclamation Ditch is listed as impaired for copper, fecal pathogens, low dissolved oxygen, nitrate, nutrients, organics, pesticides, $\mathrm{pH}$, turbidity, and toxicity under the Clean Water Act Section 303(d) [96]. Diversion of up to 2.5 million $\mathrm{m}^{3} / \mathrm{y}$ (2000 AFY) is permitted, provided that minimum ecological flows are maintained [98]. During a typical normal or wet year, M1W estimates that up to 1.0 million $\mathrm{m}^{3} / \mathrm{y}$ ( $808 \mathrm{AFY}$ ) would be available for diversion [71]. Presently, the Reclamation Ditch contributes approximately 0.7 million $\mathrm{m}^{3} / \mathrm{y}$ (555 AFY), or 11\%, of the PWM source water, supplied during the months of March through November [71].

Appendix A.1.3. Ag Wash

The Salinas Industrial Wastewater Treatment Facility (SIWTF) receives ag wash water from 25 food processing operations, with over $80 \%$ of flow coming from the rinsing of vegetables (Figure 3) [13]. In 2019, the facility handled 2.7 million $\mathrm{m}^{3} / \mathrm{y}$ (2200 AFY) of industrial wastewater, with peak flows occurring in May and minimum flows occurring in September [99]. Formerly, the SIWTF aeration basin discharged to either percolation ponds or to rapid infiltration beds [100]. Today, the PWM project redirects treated effluent from the SIWTF to the front of the RTP during the summer months when irrigation demand is highest [47]. During the remainder of the year when ag wash is not needed, the percolation ponds provide up to 1.3 million $\mathrm{m}^{3}$ (1065 AF) of seasonal storage for summer use [44].

Appendix A.1.4. Salinas Stormwater

Urban runoff from $6.5 \mathrm{~km}^{2}\left(2.5 \mathrm{mi}^{2}\right)$ in the southern part of Salinas is conveyed separately from the Reclamation Ditch [13]. This runoff is combined with ag wash water at the SIWTF, yielding an estimated 3.8 million $\mathrm{m}^{3} / \mathrm{y}$ (3100 AFY) available for recycling during a typical normal or wet year [71]. Presently, these combined sources contribute approximately 0.6 million $\mathrm{m}^{3} / \mathrm{y}$ (513 AFY), or $10 \%$, of the PWM source water, supplied primarily during the months of March through May [71]. 
Appendix A.1.5. Municipal Wastewater

During a typical normal or wet year, up to 7.2 million $\mathrm{m}^{3} / \mathrm{y}$ (5800 AFY) of secondary municipal wastewater effluent would be available for advanced purification [71]. Presently, the secondary effluent contributes approximately 2.3 million $\mathrm{m}^{3} / \mathrm{y}$ (1885 AFY), or 37\%, of the PWM source water, supplied primarily during the months of November through March when the need for agricultural irrigation water is lowest [71].

An additional 0.3 million $\mathrm{m}^{3} / \mathrm{y}$ (244 AFY), or $5 \%$, of the PWM source water is sourced from various recycled and backwash flows generated at the treatment plants [71].

\section{Appendix A.2. Recycled Water Treatment \& Storage}

\section{Appendix A.2.1. Treatment Concerns}

Several of the new sources introduced by PWM have quality impairment concerns, so capturing and treating this water benefits stormwater and runoff management efforts in Monterey County. For instance, median total nitrogen levels of $25 \mathrm{mg} / \mathrm{L}$ and $70 \mathrm{mg} / \mathrm{L}$ as $\mathrm{N}$ were measured for the untreated ag wash and Blanco Drain sources, respectively, while the advanced treated water met Title 22 requirements of $10 \mathrm{mg} / \mathrm{L}$ total nitrogen [13]. Similarly, the ag wash and Blanco Drain sources had median total organic carbon (TOC) levels of $295 \mathrm{mg} / \mathrm{L}$ and $3 \mathrm{mg} / \mathrm{L}$, respectively, whereas the advanced treated water for potable reuse met Title 22 requirements of $0.5 \mathrm{mg} / \mathrm{L}$ TOC [13]. Legacy pesticides dieldrin and dichlorodiphenyldichloroethylene (DDE) were detected in the Blanco Drain source but removed effectively at the RTP [13]. Water quality improvements between the source and finished water are achieved through dilution of blended source waters, primary and secondary treatment processes, and post-secondary treatment processes.

\section{Appendix A.2.2. Tertiary Treatment Selection}

All source waters entering the Regional Treatment Plant undergo primary and secondary treatment (Figure 4). Secondary effluent is allocated among parallel streams of advanced treatment, tertiary treatment, and the ocean outfall, depending on current recycled water demand. To reduce levels of total dissolved solids (TDS) in the recycled water streams, M1W receives certain high-TDS wastes by truck, such as water softener wastes, which are added to the secondary effluent destined for ocean discharge [13].

The tertiary treatment of flocculation, in-line filtration, and chlorination produces nonpotable recycled water for CSIP irrigation [43]. This treatment train was piloted during the Monterey Wastewater Reclamation Study for Agriculture as an abbreviated version of California's Title 22 treatment process, which required higher coagulant doses and a sedimentation step prior to filtration [27]. Pilot testing demonstrated that the in-line filtration tertiary treatment train produced safe irrigation water at two-thirds or less of the cost of the conventional Title 22 process [27].

\section{Appendix A.2.3. Regulatory Context for Subsurface Storage of Recycled Water}

The State Water Resources Control Board regulates the treatment and use of recycled water under the California Code of Regulations Title 22, Division 4 [101]. For indirect potable reuse through the PWM groundwater replenishment project, seasonal storage occurs in the groundwater basin, which also serves as the required environmental buffer providing pathogen reduction and failure response time. However, the Title 22 discussion does not include recycled water that is applied to the subsurface but not intended for potable groundwater replenishment, as would be the case for the perched aquifer storage of tertiary treated water at Armstrong Ranch. While the tertiary recycled water does not meet drinking water standards, discharge of lower-quality effluent to the subsurface is not always prohibited [102,103]. Consistent with California's Antidegradation Policy (Resolution No. 68-16), M1W would need to demonstrate that recycled water storage at Armstrong Ranch would not compromise groundwater or surface water quality [104]. Beyond that, however, it is unclear 
what other environmental and public health requirements also apply. Additional regulatory guidance clarifying these requirements would support expanded storage opportunities and other recycled water innovations.

\section{Appendix A.2.4. Pure Water Monterey Treatment System Design}

Advanced treatment that includes ozone, membrane filtration (MF), reverse osmosis (RO), and $\mathrm{UV} / \mathrm{H}_{2} \mathrm{O}_{2}$ advanced oxidation is used to produce potable recycled water for groundwater replenishment [39]. For groundwater replenishment projects with subsurface injection, indirect potable reuse regulations from the State Water Resources Control Board Division of Drinking Water require full advanced treatment including RO and advanced oxidation [101]. Ozonation followed by membrane filtration was selected as pretreatment for reverse osmosis [40]. Ozone pretreatment can reduce MF fouling by oxidizing large ( $>10 \mathrm{kDa})$ organic molecules in the secondary effluent, yielding smaller molecules $(<1 \mathrm{kDa})$ that instead pass through the MF membranes and are later rejected by RO [13]. In addition to improving MF performance, the ozone pretreatment provides added disinfection and destruction of many contaminants of emerging concern [13].

To evaluate the performance of the advanced treatment train and to refine operational parameters for full-scale design, pilot-scale testing was performed between October 2013 and July 2014 [40]. As M1W was evaluating ozone pretreatment for the PWM project, project leaders had identified only one other entity that used this treatment approach for non-nitrified secondary wastewater effluent [13]. The West Basin Municipal Water District in Los Angeles County, CA, had just installed ozone pretreatment at its Edward C. Little Water Recycling Facility in 2013 [105]. Whereas West Basin had demonstrated the potential effectiveness of ozone pretreatment to improve MF performance [106], this treatment strategy was untested for the unique blend of source waters utilized by PWM. The PWM pilot study revealed that ozone pretreatment reduced fouling of the MF membranes, extending MF run times by a factor of four and supporting higher MF fluxes, which translated to cost and space savings at full scale [40].

\section{References}

1. Luthy, R.G.; Wolfand, J.M.; Bradshaw, J.L. Urban Water Revolution: Sustainable Water Futures for California Cities. J. Environ. Eng. 2020, 146, 04020065. [CrossRef]

2. Greater Monterey County Regional Water Management Group. Integrated Regional Water Management Plan for the Greater Monterey County Region; Greater Monterey County Integrated Regional Water Management Program: Greater Monterey County, CA, USA, 2013.

3. Swain, D.L.; Langenbrunner, B.; Neelin, J.D.; Hall, A. Increasing Precipitation Volatility in Twenty-FirstCentury California. Nat. Clim. Chang. 2018, 8, 427-433. [CrossRef]

4. Monterey County Convention \& Visitors Bureau. MCCVB 2018-19 Annual Report; Monterey County Convention \& Visitors Bureau: Monterey, CA, USA, 2019.

5. Monterey County Agricultural Commissioner. Monterey County 2019 Crop Report: Invasive Species; Monterey County Agricultural Commissioner: Salinas, CA, USA, 2020.

6. Annual Crop Report. Available online: http://montereycfb.com/index.php?page=annual-crop-report (accessed on 17 August 2020).

7. Monterey County Water Resources Agency; State Coastal Conservancy. Salinas River Long-Term Management Plan; Monterey County Water Resources Agency: Salinas, CA, USA, 2019.

8. Lund, J.; Medellin-Azuara, J.; Durand, J.; Stone, K. Lessons from California's 2012-2016 Drought. J. Water Resour. Plan. Manag. 2018, 144, 04018067. [CrossRef]

9. Richter, B.D.; Benoit, K.; Dugan, J.; Getacho, G.; LaRoe, N.; Moro, B.; Rynne, T.; Tahamtani, M.; Townsend, A. Decoupling Urban Water Use and Growth in Response to Water Scarcity. Water 2020, 12, 2868. [CrossRef]

10. Water on the Monterey Peninsula. Available online: https://www.montereywaterinfo.org/about-us/water-onthe-monterey-peninsula/ (accessed on 19 August 2020). 
11. Food \& Water Watch. Top Ten Most Expensive Water Providers in the Country: 2017 Update; Food \& Water Watch: Oakland, CA, USA, 2017.

12. Hanak, E.; Mount, J.; Chappelle, C. Just the Facts: California's Latest Drought; Public Policy Institute of California Water Policy Center: San Francisco, CA, USA, 2016.

13. Nellor Environment Associates; Trussell Technologies; Todd Groundwater. Final Engineering Report: Monterey One Water Pure Water Monterey Groundwater Replenishment Project; Pure Water Monterey: Monterey, CA, USA, 2019.

14. State Water Resources Control Board. Order on Four Complaints Filed Against The California-American Water Company (WR 95-10); State Water Resources Control Board: Sacramento, CA, USA, 1995.

15. State Water Resources Control Board. Order WR 2009-0060; State Water Resources Control Board: Sacramento, CA, USA, 2009; pp. 1-64.

16. State Water Resources Control Board. Resolution No. 2016-0040; State Water Resources Control Board: Sacramento, CA, USA, 2016; pp. 1-27.

17. Water Supply Planning Committee. Agenda; Monterey Peninsula Water Management District: Monterey, CA, USA, 2019.

18. Agenda: Special Meeting and Closed Session. Available online: https://www.mpwmd.net/asd/board/ boardpacket/2016/20160127/Jan-27-Meeting-Agenda.htm (accessed on 17 August 2020).

19. California American Water v. City of Seaside, et Al., Case No. M66343; Monterey County Superior Court: Salinas, CA, USA, 2006.

20. Seawater Intrusion Monitoring. Available online: https://www.co.monterey.ca.us/government/governmentlinks/water-resources-agency/programs/seawater-intrusion-monitoring (accessed on 17 August 2020).

21. Salinas Valley Basin Groundwater Sustainability Agency. Salinas Valley Groundwater Basin 180/400-Foot Aquifer Subbasin Groundwater Sustainability Plan; Salinas Valley Basin Groundwater Sustainability Agency: Salinas, CA, USA, 2020.

22. History. Available online: https://montereyonewater.org/185/History (accessed on 19 August 2020).

23. Monterey Regional Water Pollution Control Agency. Joint Exercise of Powers Agreement for the Monterey Regional Water Pollution Control Agency; Monterey Regional Water Pollution Control Agency: Monterey, CA, USA, 1989.

24. Service Area. Available online: https://montereyonewater.org/266/Service-Area (accessed on 19 August 2020).

25. Recycled Water. Available online: https://montereyonewater.org/252/Recycled-Water (accessed on 19 August 2020).

26. State Water Resources Control Board. Water Quality Control Plan: Central Coastal Basin; State Water Resources Control Board: Sacramento, CA, USA, 1975.

27. Engineering-Science. Monterey Wastewater Reclamation Study for Agriculture; Engineering-Science: Berkeley, CA, USA, 1987.

28. Regional Treatment Plant. Available online: https://montereyonewater.org/280/Regional-Treatment-Plant (accessed on 19 August 2020).

29. Haddad, B.M. Monterey County Water Recycling Project: Institutional Study. J. Water Resour. Plan. Manag. 2002, 128, 280-287. [CrossRef]

30. Monterey County Water Resources Agency. Recommendations to Address the Expansion of Seawater Intrusion in the Salinas Valley Groundwater Basin; Monterey County Water Resources Agency: Salinas, CA, USA, 2017.

31. Recycled Water. Available online: https://www.irwd.com/services/recycled-water (accessed on 18 August 2020).

32. Reed, J.R. Grower Attitudes towards Water Management Strategies While Mitigating Seawater Intrusion: A Case Study of the Castroville Seawater Intrusion Project. Master's Thesis, San Jose State University, San Jose, CA, USA, 2017. [CrossRef]

33. John Doe13k. Can Pure Water Monterey Recycled Water Replace Cal Am's Desal? [Video]. Youtube, 2018.

34. About Pure Water Monterey. Available online: https://purewatermonterey.org/about-us/ (accessed on 19 August 2020).

35. Recycled Water Committee. Agenda; Monterey One Water: Monterey, CA, USA, 2020; pp. 1-80.

36. California Public Utilities Comission; Monterey Bay National Marine Sanctuary. CalAm Monterey Peninsula Water Supply Project: Final Environmental Impact Report/Environmental Impact Statement; National Oceanic and Atmospheric Administration Office of National Marine Sanctuaries: Silver Spring, MD, USA, 2018. 
37. Pure Water Monterey: A Regional Solution for a Regional Issue. Available online: https://purewatermonterey. org/ (accessed on 19 August 2020).

38. Dodder, N.G.; Maruya, K.A.; Lee Ferguson, P.; Grace, R.; Klosterhaus, S.; La Guardia, M.J.; Lauenstein, G.G.; Ramirez, J. Occurrence of Contaminants of Emerging Concern in Mussels (Mytilus Spp.) along the California Coast and the Influence of Land Use, Storm Water Discharge, and Treated Wastewater Effluent. Mar. Pollut. Bull. 2014, 81, 340-346. [CrossRef] [PubMed]

39. Project Technology. Available online: https://purewatermonterey.org/about-us/project-technology/ (accessed on 19 August 2020).

40. Trussell Technologies; Separation Processes. Pure Water Monterey Groundwater Replenishment Project: Advanced Water Treatment Facility Piloting. In Final Engineering Report: Pure Water Monterey Groundwater Replenishment Project; Pure Water Monterey: Monterey, CA, USA, 2016.

41. Aldeguer Esquerdo, A.; Varo Galvañ, P.J.; Sentana Gadea, I.; Prats Rico, D. Activated Carbon and Ozone to Reduce Simazine in Water. Water 2020, 12, 2900. [CrossRef]

42. Akel Engineering Group. Marina Coast Water District 2019 Recycled Water Master Plan Draft; Akel Engineering Group: Fresno, CA, USA, 2019.

43. Tertiary Treatment Process. Available online: https://montereyonewater.org/214/Tertiary-Treatment-Process (accessed on 19 August 2020).

44. Schaaf \& Wheeler Consulting Civil Engineers. Proposed Modifications to the Pure Water Monterey Groundwater Replenishment Project-Source Water Availability, Yield, and Use [Memorandum]. In Draft Supplemental Environmental Impact Report for the Proposed Modifications to the Pure Water Monterey Groundwater Replenishment Project; Schaaf \& Wheeler Consulting Civil Engineers: Salinas, CA, USA, 2019.

45. Monterey Regional Water Pollution Control Agency; Monterey County Water Resources Agency. Amended and Restated Water Recycling Agreement between Monterey Regional Water Pollution Control Agency and Monterey County Water Resources Agency; Monterey Regional Water Pollution Control Agency: Monterey, CA, USA, 2015.

46. Holden, B.; Imamura, A. Approved Pure Water Monterey (PWM) Project and Proposed Modifications to Expand the PWM Project-Source Water Operational Plan; Monterey One Water: Monterey, CA, USA, 2020.

47. Monterey One Water. Progress Report on Pure Water Monterey Expansion; Monterey One Water: Monterey, CA, USA, 2018.

48. Monterey One Water; Monterey Peninsula Water Management District. Draft Supplemental Environmental Impact Report for the Proposed Modifications to the Pure Water Monterey Groundwater Replenishment Project; Monterey One Water: Monterey, CA, USA, 2019.

49. Monterey Regional Water Pollution Control Agency; Marina Coast Water District. Pure Water Delivery and Supply Project Agreement between Monterey Regional Water Pollution Control Agency and Marina Coast Water District; Monterey Regional Water Pollution Control Agency: Monterey, CA, USA, 2016.

50. Schaaf \& Wheeler Consulting Civil Engineers. Marina Coast Water District 2015 Urban Water Management Plan; Schaaf \& Wheeler Consulting Civil Engineers: Salinas, CA, USA, 2016.

51. California Public Utilities Commission. Chapter 5: Regional Project Description. In California American Water Company Coastal Water Project: Draft Environmental Impact Report; California Public Utilities Commission: San Francisco, CA, USA, 2009.

52. Arellano-Gonzalez, J.; Moore, F.C. Intertemporal Arbitrage of Water and Long-Term Agricultural Investments: Drought, Groundwater Banking, and Perennial Cropping Decisions in California. Am. J. Agric. Econ. 2020, 102, 1368-1382. [CrossRef]

53. Central Coast Regional Water Quality Control Board. Order No. R3-2018-0017, NPDES No. CA0048551, Waste Discharge Requirements for the Monterey One Water Regional Wastewater Treatment Plant and Advanced Water Purification Facility Discharge to the Pacific Ocean; Central Coast Regional Water Quality Control Board: San Luis Obispo, CA, USA, 2018.

54. Cook, J.; Duffy, J. Monterey GWR Project: A Sustainable Return on Investment Assessment of Desalination and Water Reuse; HDR: Omaha, NE, USA, 2017.

55. California Tax Data. What Is Proposition 218; California Tax Data: Irvine, CA, USA, 2002.

56. Text of Prop. 218 with Analysis. Available online: https://www.hjta.org/propositions/proposition-218/textproposition-218-analysis/ (accessed on 18 August 2020). 
57. Capistrano Taxpayers Association, Inc. v. City of San Juan Capistrano, Case No. 30-2012-00594579; Orange County Superior Court: Santa Ana, CA, USA, 2013.

58. Capistrano Taxpayers Association, Inc. v. City of San Juan Capistrano, Case No. G048969; Fourth District Division Three Court of Appeals: Santa Ana, CA, USA, 2015.

59. Capistrano Taxpayers Association v. City of San Juan Capistrano-What the Appellate Court's Ruling Means. Available online: https://www.foleymansfield.com/newsroom/capistrano-taxpayers-association-v-city-sanjuan-capistrano-what-appellate-courts-ruling-means/ (accessed on 18 August 2020).

60. Monterey Peninsula Water Management District. Water Supply Charge; Monterey Peninsula Water Management District: Monterey, CA, USA, 2012.

61. League of California Cities. Proposition 218 Implementation Guide; League of California Cities: Sacramento, CA, USA, 2007.

62. Monterey County Board of Supervisors. Board Order: Resolution No. 20-205; Monterey County Board of Supervisors: Salinas, CA, USA, 2020.

63. California Public Utilities Commission. Decision Approving a Modified Monterey Peninsula Water Supply Project, Adopting Settlement Agreements, Issuing Certificate of Public Convenience and Necessity and Certifying Combined Environmental Report; California Public Utilities Commission: San Francisco, CA, USA, 2018.

64. Stoldt, D.J. Supply and Demand for Water on the Monterey Peninsula; Monterey Peninsula Water Management District: Monterey, CA, USA, 2020.

65. California Coastal Commission. Staff Report: Recommendation on Appeal Substantial Issue E De Novo Hearing and Consolidated Coastal Development Permit; California Coastal Commission: San Francisco, CA, USA, 2019.

66. Welcome. Available online: https://www.citizensforjustwater.org/ (accessed on 18 August 2020).

67. Cal Am Desalination Project. Available online: https://www.cityofmarina.org/935/Cal-Am-DesalinationProject (accessed on 18 August 2020).

68. Crooks, I.C. Agenda Items Th3a \& 4a; California American Water Company: San Diego, CA, USA, 2020.

69. Xia, R. Water Company Withdraws Desalination Proposal as Battle over Environmental Justice Heats Up. Los Angeles Times, 16 September 2020.

70. Luster, T. Notice of Incomplete Coastal Development Permit Application; California Coastal Commission: San Francisco, CA, USA, 2020.

71. Monterey One Water; Monterey Peninsula Water Management District. Final Supplemental Environmental Impact Report for the Proposed Modifications to the Pure Water Monterey Groundwater Replenishment Project; Monterey One Water: Monterey, CA, USA, 2020.

72. John Doe13k. Coastal Commission Hearing on Cal Am's Desal Permit-Propose CalAm Desal [Video]. Youtube, 2019.

73. Mayer, P. Supplemental Expert Report and Recommendations of Peter Mayer, P.E., Regarding Water Supply and Demand in the California American Water Company's Monterey Main System; Water Demand Management: Boulder, CO, USA, 2020.

74. Di Lorenzo, E. The Monterey Desalination Plant-Richard Svindland [Video]. Youtube, 2019.

75. Williams, D.E. Slant Well Intake Systems: Design and Construction. In Intakes and Outfalls for Seawater Reverse-Osmosis Desalination Facilities: Innovations and Environmental Impacts; Springer: Cham, Switzerland, 2015; pp. 275-320. [CrossRef]

76. Goebel, M.; Knight, R.; Halkjær, M. Mapping Saltwater Intrusion with an Airborne Electromagnetic Method in the Offshore Coastal Environment, Monterey Bay, California. J. Hydrol. Reg. Stud. 2019, 23, 100602. [CrossRef]

77. Farella Braun + Martel LLP. Marina Draft EIR Comment Letter; Farella Braun + Martel LLP: San Francisco, CA, USA, 2017.

78. John Doe13k. Coastal Commission Hearing on Cal Am's Desal Permit- Oppose CalAm Desal [Video]. Youtube, 2019.

79. Measure, J. Full Ballot Measure. Available online: https://www.mpwmd.net/resources/measure-j-information/ measure-j-full-ballot-measure/ (accessed on 18 August 2020).

80. Measure J Information. Available online: https://www.mpwmd.net/resources/measure-j-information/ (accessed on 18 August 2020). 
81. Raftelis Financial Consultants. Monterey Peninsula Water Management District: Preliminary Valuation and Cost of Service Analysis Report; Raftelis Financial Consultants: Charlotte, NC, USA, 2019.

82. Monterey Peninsula Water Management District; Rincon Consultants. Potential Acquisition of Monterey Water System and District Boundary Adjustment; Monterey Peninsula Water Management District: Monterey, CA, USA, 2020.

83. About PWN. Available online: http://www.publicwaternow.org/about_pwn (accessed on 18 August 2020).

84. Email List. Available online: https://purewatermonterey.org/public-participation/email-list/ (accessed on 19 August 2020).

85. Community Outreach. Available online: https://montereyonewater.org/236/Community-Outreach (accessed on 19 August 2020).

86. Welcome to the Our New Website. Available online: https://montereyonewater.org/CivicAlerts.aspx?AID=12 (accessed on 19 August 2020).

87. Qin, Y.; Horvath, A. Use of Alternative Water Sources in Irrigation: Potential Scales, Costs, and Environmental Impacts in California. Environ. Res. Commun. 2020, 2, 055003. [CrossRef]

88. Luthy, R.G.; Sedlak, D.L. Urban Water-Supply Reinvention. Daedalus 2015, 144, 72-82. [CrossRef]

89. System Delivery. Available online: https://www.watersupplyproject.org/system-delivery (accessed on 30 October 2020).

90. Di Baldassarre, G.; Wanders, N.; AghaKouchak, A.; Kuil, L.; Rangecroft, S.; Veldkamp, T.I.E.; Garcia, M.; van Oel, P.R.; Breinl, K.; Van Loon, A.F. Water Shortages Worsened by Reservoir Effects. Nat. Sustain. 2018, 1, 617-622. [CrossRef]

91. Gonzales, P.; Ajami, N. Social and Structural Patterns of Drought-Related Water Conservation and Rebound. Water Resour. Res. 2017, 53, 10619-10634. [CrossRef]

92. Mayer, P. Expert Report and Recommendations of Peter Mayer, P.E. Regarding Water Supply and Demand in the California American Water Company's Monterey Main System; Water Demand Management: Boulder, CO, USA, 2020.

93. Palazzo, J.; Liu, O.R.; Stillinger, T.; Song, R.; Wang, Y.; Hiroyasu, E.H.T.; Zenteno, J.; Anderson, S.; Tague, C. Urban Responses to Restrictive Conservation Policy during Drought. Water Resour. Res. 2017, 53, 4459-4475. [CrossRef]

94. Pincetl, S.; Porse, E.; Cheng, D. Fragmented Flows: Water Supply in Los Angeles County. Environ. Manag. 2016, 58, 208-222. [CrossRef] [PubMed]

95. Reichert, P.; Langhans, S.D.; Lienert, J.; Schuwirth, N. The Conceptual Foundation of Environmental Decision Support. J. Environ. Manag. 2015, 154, 316-332. [CrossRef] [PubMed]

96. Impaired Water Bodies. Available online: https://www.waterboards.ca.gov/water_issues/programs/tmdl/ integrated2014_2016.shtml (accessed on 18 August 2020).

97. State Water Resources Control Board. Right to Divert and Use Water: Permit 21376; State Water Resources Control Board: Sacramento, CA, USA, 2017.

98. State Water Resources Control Board. Right to Divert and Use Water: Permit 21377; State Water Resources Control Board: Sacramento, CA, USA, 2017.

99. City of Salinas. Industrial Wastewater Treatment Facility 2019 Annual Report; City of Salinas: Salinas, CA, USA, 2020.

100. Industrial Waste Facility. Available online: https://www.cityofsalinas.org/our-city-services/public-works/waterwaste-energy/environmental-maintenance-services/industrial-waste-facility (accessed on 18 August 2020).

101. State Water Resources Control Board. Regulations Related to Recycled Water; State Water Resources Control Board: Sacramento, CA, USA, 2018.

102. Carollo Engineers. City of Fresno Recycled Water Master Plan; Carollo Engineers: Walnut Creek, CA, USA, 2010.

103. State Water Resources Control Board. Order WQ 2014-0153-DWQ: General Waste Discharge Requirements for Small Domestic Wastewater Treatment Systems; State Water Resources Control Board: Sacramento, CA, USA, 2014.

104. State Water Resources Control Board. Resolution No. 68-16: Statement of Policy With Respect to Maintaining High Quality of Waters in California; State Water Resources Control Board: Sacramento, CA, USA, 1968. 
105. Water Projects: Edward C. Little Water Recycling Facility Phase V Design-Build Expansion. Available online: http://butier.com/project/edward-c-little-water-recycling-facility-phase-v-design-build-expansion/ (accessed on 19 August 2020).

106. Featured Projects: West Basin MWD Ozone Pretreatment. Available online: http://trusselltech.com/projects/ featured-projects/ozone-pretreatment-of-secondary-effluent-for-microfiltration-for-west-basin-mwd (accessed on 19 August 2020).

Publisher's Note: MDPI stays neutral with regard to jurisdictional claims in published maps and institutional affiliations.

(C) 2020 by the authors. Licensee MDPI, Basel, Switzerland. This article is an open access article distributed under the terms and conditions of the Creative Commons Attribution (CC BY) license (http://creativecommons.org/licenses/by/4.0/). 